\title{
cis-trans Isomerization of silybins A and B
}

\author{
Michaela Novotná ${ }^{\ddagger 1}$, Radek Gažák ${ }^{\ddagger 1,2}$, David Biedermann ${ }^{1}$, \\ Florent Di Meo ${ }^{3,4}$, Petr Marhol ${ }^{1}$, Marek Kuzma ${ }^{1}$, Lucie Bednárová ${ }^{5}$, \\ Kateřina Fuksová ${ }^{1}$, Patrick Trouillas ${ }^{3,6,7}$ and Vladimír Křen ${ }^{* 1}$
}

\section{Full Research Paper}

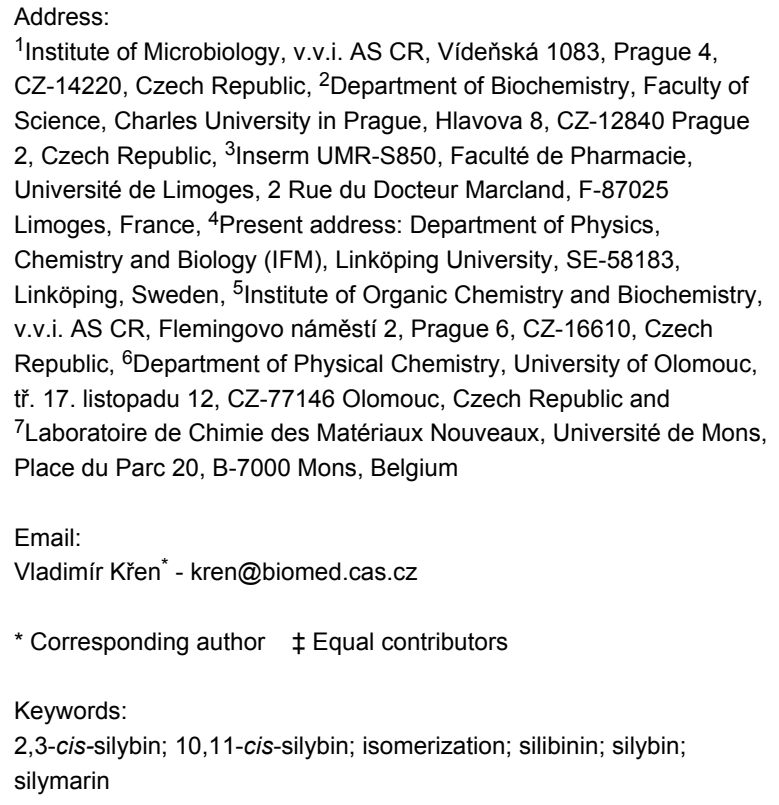

Beilstein J. Org. Chem. 2014, 10, 1047-1063.

doi:10.3762/bjoc.10.105

Received: 04 December 2013

Accepted: 04 April 2014

Published: 08 May 2014

Associate Editor: S. Bräse

(C) 2014 Novotná et al; licensee Beilstein-Institut. License and terms: see end of document.

\begin{abstract}
Methods were developed and optimized for the preparation of the 2,3-cis- and the 10,11-cis-isomers of silybin by the Lewis acid catalyzed $\left(\mathrm{BF}_{3} \cdot \mathrm{OEt}_{2}\right)$ isomerization of silybins $\mathrm{A}(\mathbf{1 a})$ and $\mathrm{B}(\mathbf{1 b})$ (trans-isomers). The absolute configuration of all optically pure compounds was determined by using NMR and comparing their electronic circular dichroism data with model compounds of known absolute configurations. Mechanisms for cis-trans-isomerization of silybin are proposed and supported by quantum mechanical calculations.
\end{abstract}

\section{Introduction}

The flavonolignan silybin (alternative name silibinin), occurring in the fruits of Silybum marianum (milk thistle), consists of two stereoisomers - silybin A (1a) and B (1b) - in a ca. 1:1 ratio (Figure 1). Their absolute configuration is known [1,2] and their separation was accomplished recently [3-5]. Both silybin isomers as well as other flavonolignans from silymarin (crude defatted extract from the fruits of $S$. marianum) are products of a phenolic oxidative coupling of the flavonoid taxifolin and the lignan coniferyl alcohol. The mechanism of this coupling reaction was described [6] and implied a 10,11-trans relative con- 
figuration, as in all the major components of silymarin. Little is known about the structures of the minor components of silymarin. It was speculated that some of them were 10,11-cisanalogues of the major silymarin constituents [7], but these minor components were never isolated in sufficient amount and purity to enable such unwarranted hypotheses to be verified $[8,9]$. Another study focusing on the minor components of silymarin identified two new compounds isosilybin C (3) and D (4), however these were shown to be regioisomers of isosilybins $\mathrm{A}$ (5) and B (6) [10] (Figure 2).

Other authors reported 2,3-cis-isomers of silybin [11,12], the relative configuration of which were corroborated by ${ }^{1} \mathrm{H}$ NMR coupling constants, i.e., $J_{2,3}$ of ca. $11 \mathrm{~Hz}$ in the trans-isomers and $2-3 \mathrm{~Hz}$ in the cis-isomers. Nevertheless, their absolute configurations remained unknown. The origin of the cis-isomers either as biosynthetic side products or as artifacts formed during their isolation is also unknown.

The isolation of naturally occurring cis-isomers in the pure form and their complete structure identification would be the only unambiguous way how to prove identity of natural and synthetic cis-isomers. Unfortunately, the conventional identification by LC-MS or UV-vis scanning is inadequate as the major and minor compounds exhibit the same MS and UV profiles.
The content of silybin cis-isomers in silymarin is presumably very low. The composition of silymarin strongly depends upon its source, which is influenced by the variety of $S$. marianum and by the cultivation, harvest and processing conditions. Variations of the minority content (not only silybin cis-isomers) is even more pronounced. Therefore, their identification in a particular silymarin preparation would have only limited information value.

Silybin is an important pharmaceutical commodity and a complete understanding of its composition is needed in order to understand its pharmaceutical properties. Therefore, the detailed structural knowledge and availability of (potential) minor impurities is a fundamental requisite, e.g., for master file assembly.

The aim of this work was to prepare stereochemically pure 2,3cis- and 10,11-cis-isomers of silybin A (1a) and B (1b) by a Lewis acid catalyzed isomerization to determine their absolute configuration and to propose a mechanism for the cis-transisomerization processes.

\section{Results and Discussion Chemistry}

In our previous work on the enzymatic kinetic resolution of silybin $[4,5], \mathrm{BF}_{3} \cdot \mathrm{OEt}_{2}$ in EtOAc was found to catalyze the transesterification of silybin to yield not only 23-O-<smiles>[R]C[C@H]1Oc2ccc([C@@H]3Oc4cc(O)cc(O)c4C(=O)[C@H]3O)cc2O[C@H]1c1ccc(O)c(OC)c1</smiles>

1a: $\mathrm{R}=\mathrm{H}$; silybin $\mathrm{A}(2 R, 3 R, 10 R, 11 R)$

2a: $R=A c ; 23-O$-acetylsilybin $A$<smiles>[R]C[C@H]1Oc2ccc([C@@H]3Oc4cc(O)cc(O)c4C(=O)[C@H]3O)cc2O[C@H]1c1ccc(O)c(OC)c1</smiles>

1b: $\mathrm{R}=\mathrm{H}$; silybin $\mathrm{B}(2 R, 3 R, 10 \mathrm{~S}, 11 \mathrm{~S})$

2b: $R=A c ; 23-O$-acetylsilybin $B$

Figure 1: Selected naturally occurring trans-silybins and their acetates.<smiles>[R]c1cc([C@H]2Oc3ccc([C@@H]4Oc5cc(O)cc(O)c5C(=O)[C@H]4O)cc3O[C@H]2CO)cc(OC)c1[R]</smiles>

5: $\mathrm{R}^{1}=\mathrm{OH}, \mathrm{R}^{2}=\mathrm{H}$ : isosilybin $\mathrm{A}$

3: $\mathrm{R}^{1}=\mathrm{H}, \mathrm{R}^{2}=\mathrm{OH}$ : isosilybin $\mathrm{C}$<smiles>[R]c1cc([C@H]2Oc3ccc([C@@H]4Oc5cc(O)cc(O)c5C(=O)[C@H]4O)cc3O[C@H]2CO)cc(OC)c1[R]</smiles>

6: $\mathrm{R}^{1}=\mathrm{OH}, \mathrm{R}^{2}=\mathrm{H}$ : isosilybin $B$

4: $\mathrm{R}^{1}=\mathrm{H}, \mathrm{R}^{2}=\mathrm{OH}$ : isosilybin $\mathrm{D}$

Figure 2: Isosilybins occurring as minor components of silymarin. 
acetylsilybin (2, ca. 90\%), but two novel compounds with UV spectra similar to that of silybin. Enzymatic alcoholysis ( $n$-butanol) of this mixture by Novozym 435 led, after a prolonged reaction time, to the removal of the acetyl groups from trans-isomers $\mathbf{2 a}$ and $\mathbf{2 b}$ to give $\mathbf{1 a}$ and $\mathbf{1 b}$ (Figure 1), while the two minor isomers remained acetylated. Separation of the resulting mixture by silica gel column chromatography yielded an inseparable mixture of the two new compounds. In HPLC they were assigned to two separate peaks with the same molecular mass ( $m / z 524) .{ }^{1} \mathrm{H}$ NMR spectra indicated that the two compounds differ only slightly from the silybin derivatives $\mathbf{2 a}$ and $\mathbf{2 b}$, respectively. The unknown compounds exhibit a $J_{10,11}$ of ca. $3 \mathrm{~Hz}$, whereas natural silybin (1) has a $J_{10,11}$ of ca. $8 \mathrm{~Hz}$. Based on this evidence, the unknown compounds from the acylation reaction were proposed to be a diastereoisomeric mixture of 23-O-acetyl-10,11-cis-silybin A (7) and B (8) (Figure 3 ) in a ca. 1:1 ratio.

As the yields of the two 10,11-cis-silybin isomers were low (ca. 10\%), we optimized the reaction conditions for better yields. In the initial screening, aimed at finding the most suitable solvent and Lewis acid (Table 1), we used natural silybin, i.e., ca. 1:1 mixture of $\mathbf{1 a}$ and $\mathbf{1 b}$.

The choice of solvent was limited by the low solubility of silybin in most organic solvents or by their incompatibility with the Lewis acid $\mathrm{BF}_{3} \cdot \mathrm{OEt}_{2}$. The following solvents were tested: EtOAc, DMF, $\mathrm{CH}_{3} \mathrm{CN}$, DMSO, $\mathrm{CHCl}_{3}$ at 0,25 , and $50{ }^{\circ} \mathrm{C}$. In
$\mathrm{CH}_{3} \mathrm{CN}$ and DMSO silybin decomposed, and in $\mathrm{CHCl}_{3}$ the reaction failed. In EtOAc, the reaction was accompanied by $\mathrm{C}$-23 $\mathrm{O}$-acetylation, which complicated the reaction mixture analysis. DMF at $50{ }^{\circ} \mathrm{C}$ was found to be the most suitable solvent for the isomerization and was used for further Lewis acid screening. Eventually, $\mathrm{BF}_{3} \cdot \mathrm{OEt}_{2}$ proved to be the most suitable Lewis acid for silybin isomerization (Table 1). Other Lewis acids either gave lower isomerization yields $\left(\mathrm{SnCl}_{4}\right)$, did not work at all, or even caused decomposition. Toluene-4sulfonic acid, as a representative protic acid, gave no reaction under the same conditions.

In this work, the preparative reactions with the two solvents DMF and EtOAc and with stereochemically pure silybin A (1a) and $\mathrm{B}$ (1b) (Figure 1) exhibited a strong dependence on the solvent. In DMF $\left(\mathrm{BF}_{3} \cdot \mathrm{OEt}_{2}, 50{ }^{\circ} \mathrm{C}\right)$, the reaction led to a single type of C-2, C-3-isomerization yielding the corresponding 2,3cis-10,11-trans-silybin A (9) and 2,3-cis-10,11-trans-silybin B (10) (Scheme 1), respectively. No C-10, C-11-isomerization was observed in this case. In EtOAc, various cis-isomers were obtained, depending on the reaction time and also on the type of starting material (1a or 1b). A detailed analysis of silybin B (1b) isomerization in EtOAc showed the formation of the 23-Oacetyl-2,3-cis-10,11-trans-isomer 11 within the first 3 hours, then it slowly disappeared, and finally 23-O-acetyl-2,3-trans10,11-cis-silybin B (12) was formed (Scheme 2). In EtOAc $\left(48 \mathrm{~h}, 80^{\circ} \mathrm{C}\right)$, $1 \mathrm{a}$ isomerized into the $23-O$-acetyl-2,3-cis-10,11trans-isomer 12 and a minor 23-O-acetyl-2,3-trans-10,11-cis-<smiles>COc1cc([C@H]2Oc3cc([C@@H]4Oc5cc(O)cc(O)c5C(=O)[C@H]4O)ccc3O[C@@H]2COC(C)=O)ccc1O</smiles>

7: 23-O-acetyl-10,11-cis-silybin A $(2 R, 3 R, 10 R, 11 S)$<smiles>COc1cc(C2Oc3cc([C@H]4Oc5cc(O)cc(O)c5C(=O)[C@H]4O)ccc3OC2COC(C)=O)ccc1O</smiles>

8: 23-O-acetyl-10,11-cis-silybin $\mathrm{B}(2 R, 3 R, 10 S, 11 R)$

Figure 3: Structures of cis-derivatives obtained by the isomerization of 1 using $\mathrm{BF}_{3} \cdot \mathrm{OEt}_{2}$ in $\mathrm{EtOAc}$

\begin{tabular}{lll} 
Table 1: Screening of suitable Lewis and protic acids for silybin isomerization. \\
Lewis acid & conversion $(\%)^{\mathrm{a}}$ & note \\
\hline $\mathrm{BF}_{3} \cdot \mathrm{OEt}_{2}$ & $15-20$ & \\
$\mathrm{SnCl}_{4}$ & $12-15$ & strong complexation, quantitative oxidation to 2,3-dehydrosilybin \\
$\mathrm{TiCl}_{4}$ & - & strong complexation \\
$\mathrm{FeCl}_{3}$ & no reaction & \\
$\mathrm{ZnCl}_{2}$ & no reaction & decomposition \\
$\mathrm{BBr}_{3}$ & - & \\
toluene-4-sulfonic acid & no reaction &
\end{tabular}

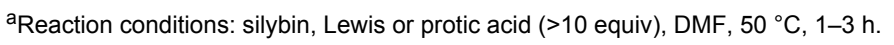


<smiles>[R]C1Oc2ccc([C@@H]3Oc4cc(O)cc(O)c4C(=O)[C@H]3O)cc2OC1[R]CO</smiles>
$\mid \begin{gathered}\mathrm{BF}_{3} \cdot \mathrm{OEt}_{2}, \mathrm{DMF} \\ 1 \mathrm{~h}, 50^{\circ} \mathrm{C}\end{gathered}$

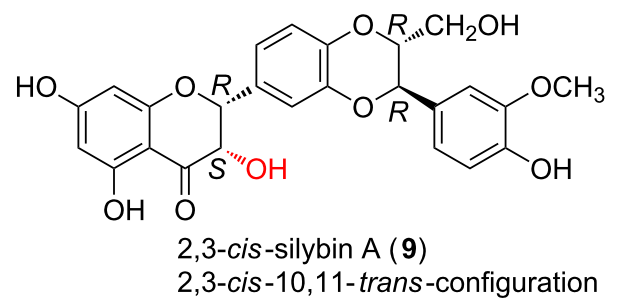

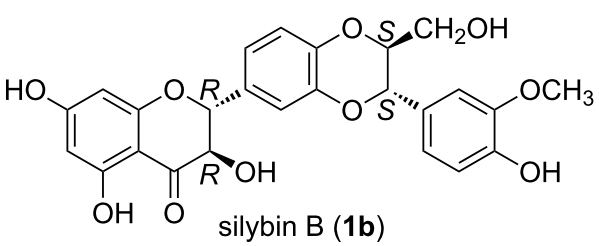
2,3-trans-10,11-trans-configuration $\mid \begin{gathered}\mathrm{BF}_{3} \cdot \mathrm{OEt}_{2}, \mathrm{DMF}, \\ 1 \mathrm{~h}, 50^{\circ} \mathrm{C}\end{gathered}$<smiles>[R]C1Oc2cc(O)cc(O)c2C(=O)[C-]1O</smiles>
2,3-cis-silybin B (10) 2,3-cis-10,11-trans-configuration

Scheme 1: Silybin A and silybin B isomerizations into their 2,3-cis-isomers (DMF).

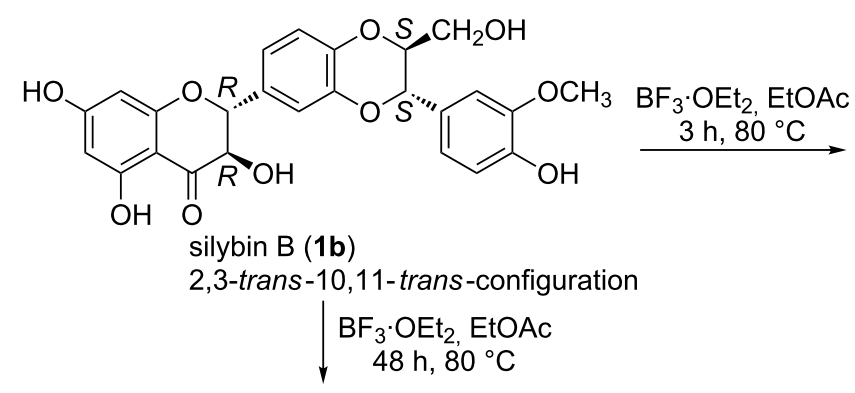

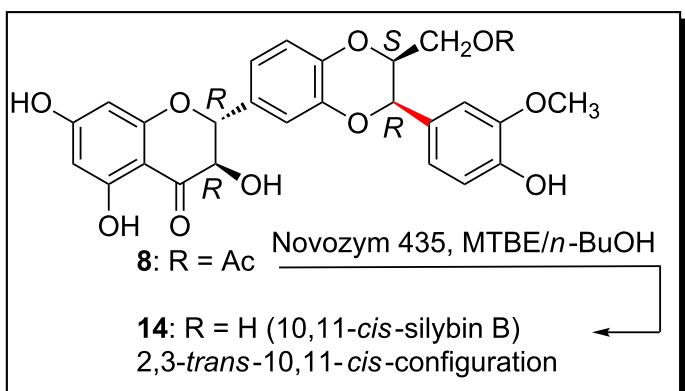

$+$

23-O-acetylsilybin B (2b)

2,3-trans-10,11-trans-configuration<smiles>[R][C@H]1Oc2cc(O)cc(O)c2C(=O)[C]1O</smiles>

23-O-acetyl-2,3-cis-silybin B (11) 2,3-cis-10,11-trans-configuration $+$ 23-O-acetylsilybin B (2b) 2,3-trans-10,11-trans-configuration isomer 13 (Scheme 3). Surprisingly, the absolute configuration at C-2, C-3 of compound $\mathbf{1 3}$ was the opposite of $\mathbf{1 a}(2 S, 3 S$ vs $2 R, 3 R$ ), which was confirmed by a comparison of their electronic circular dichroism (ECD) data. Formation of the 10,11cis-isomer with the $2 R, 3 R$ configuration was not observed during/after the isomerization of $\mathbf{1 a}$ in EtOAc. All the reactions in EtOAc were accompanied by C-23 $O$-acetylation.

\section{Separation and purification of 2,3-cis-silybins}

The separation of 2,3-cis-silybin 7 from unreacted 2,3-transsilybin 1a (or 10 from 1b) on silica gel was not feasible, analogous to the preparative separation of silybin stereoisomers 1a and 1b (Figure 1), which was a challenge for several decades. It was accomplished as the separation of the respective silybin glycosides for the first time [13,14], later by HPLC [3], and at 


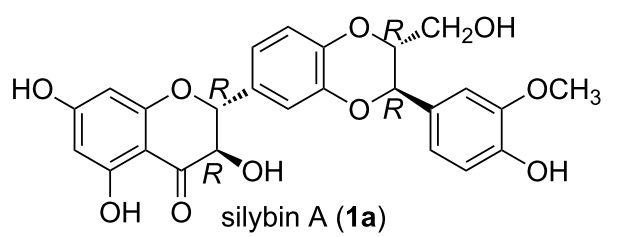

2,3-trans-10,11-trans-configuration

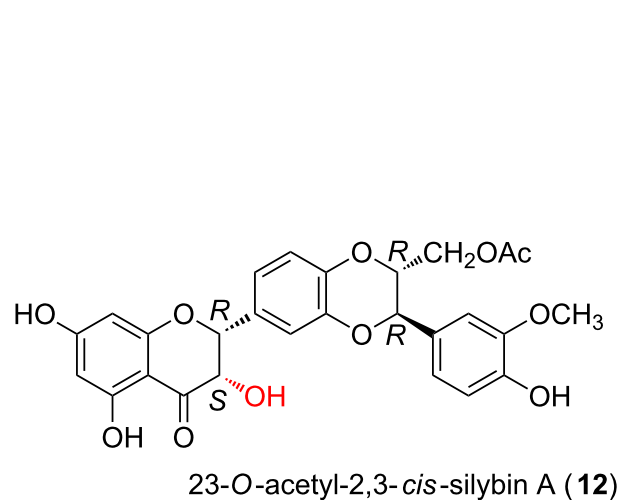

23-O-acetyl-2,3-cis-silybin A (12) 2,3-cis-10,11-trans-configuration
$\mathrm{BF}_{3} \cdot \mathrm{OEt}_{2}, \mathrm{EtOAC}$ $48 \mathrm{~h}, 80^{\circ} \mathrm{C}$

23-O-acetylsilybin A (2a)

2,3-trans-10,11-trans-configuration

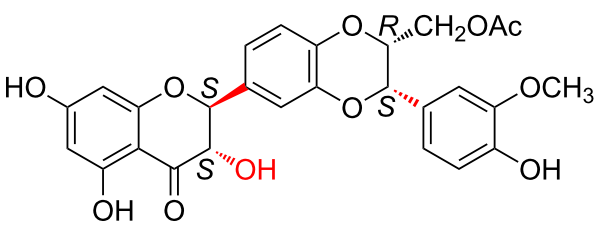

23-O-acetyl-10,11-cis-silybin (13) 2,3-trans-10,11-cis-configuration

Scheme 3: Isomerization of silybin A in EtOAc.

the preparatory scale by lipase-catalyzed discrimination $[4,5]$. However, chromatographic separation of 2,3-cis- and 2,3-transsilybins is feasible after their C-23 $\mathrm{O}$-acetylation, which can be accomplished with Novozym 435 in an acetone/vinyl acetate mixture, giving a nearly quantitative yield of the respective acetates (without the risk of further isomerization) (Scheme 4, part I). As the 2,3-trans-isomer was more abundant than the 2,3-cis-isomer its excess was removed before enzymatic acetylation by crystallizing the crude mixture from $\mathrm{MeOH} / \mathrm{H}_{2} \mathrm{O}$ 9:1, which increased the ratio of the cis/trans-isomer in the mixture from $1: 4$ to $1: 2$.

\section{Deacetylation of cis-23-O-acetylsilybins}

All pure cis-silybins were obtained as their C-23 acetates. The deacetylation proved to be rather difficult, as both acidic and basic hydrolysis as well as mild transesterification ( $\mathrm{NaOMe}$, $\mathrm{MeOH}$ ) failed and/or resulted in decomposition or reversed isomerization to the original trans-isomers. We eventually had to use enzymatic alcoholysis with a large excess of Novozym 435 and a longer reaction time (5:1, wt. enzyme/substrate, $3-5 \mathrm{~d}, 45{ }^{\circ} \mathrm{C}$ ) compared to the alcoholysis of the respective acetates of the trans-silybins. This method finally yielded pure 2,3-cis-silybins A (9) and B (10) as well as 10,11-cis-silybin B (14) (Scheme 4, parts II and III).

\section{Determination of absolute configuration of cis-silybins}

The determination of the absolute configuration of the new cissilybins by X-ray analysis is not possible, since all attempts to obtain suitable crystals using various crystallization conditions were unsuccessful. Pure silybins and their congeners are known for their poor crystallization or the formation of small crystals, which are not suitable for X-ray analysis. The absolute configuration of silybins A (1a) and B (1b) was determined indirectly on the basis of a comparison of their physicochemical data (NMR, ECD, OR). Later, these data were matched to those of their 10,11-regioisomer, isosilybin A (5) [11]. The same approach was used to determine the absolute configuration of isosilybin B (6). The only analogue that yielded suitable crystals, and hence an unequivocal determination of its absolute configuration, was 7-(4-bromobenzoyl)isosilybin A [15].

In this study the determination of the absolute configuration was based on NMR and ECD spectroscopy. Their relative configurations, i.e., the determination of trans/cis isomers at $\mathrm{C}-2, \mathrm{C}-3$ and $\mathrm{C}-10, \mathrm{C}-11$, are set by the ${ }^{1} \mathrm{H}$ NMR coupling constants $J_{2,3}$ and $J_{10,11}$, respectively. The trans-isomers exhibit $J_{2,3}$ of ca. $11 \mathrm{~Hz}$ and $J_{10,11}$ of ca. $8 \mathrm{~Hz}$, while the cis-configuration is indicated by a value of $J_{2,3}$ or $J_{10,11}$ of ca. $2-3 \mathrm{~Hz}$ $[11,12]$.

For the assignment of the absolute configuration, experimental ECD spectra of compounds $9,10,13$, and 14 were compared to those of related compounds with known absolute configurations [2]. The assignment of Cotton effects (CE) to particular regions in this molecule is based on the rough assumption that silybin and its analogues are considered to be composed of two separate $\pi$-conjugated subsystems, the 3 -hydroxyflavonone 


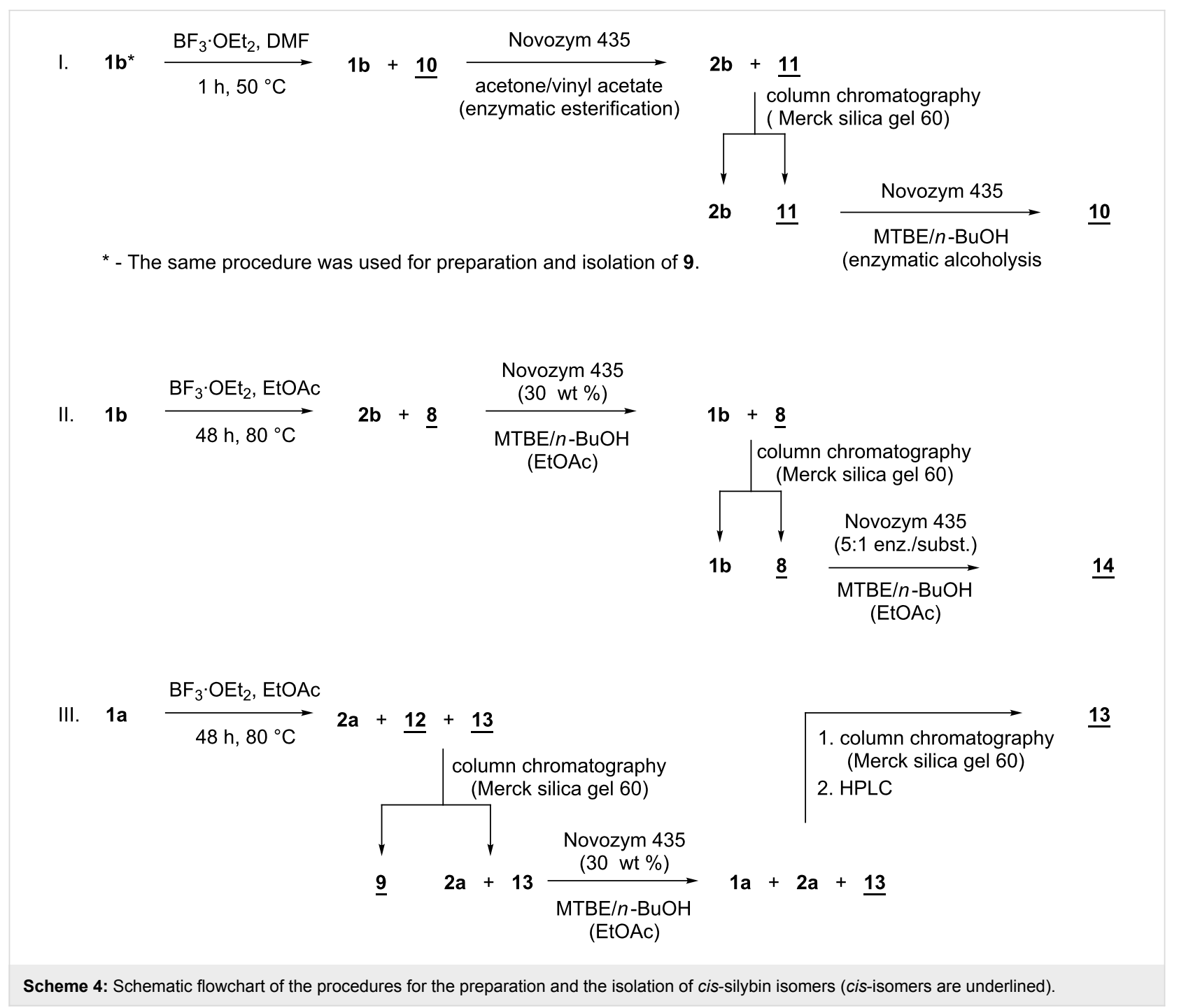

moiety (with the stereogenic centers C-2 and C-3), and the 1,4benzodioxane moiety (C-10 and C-11) (see Figure 4). In this simplification we cannot avoid the adverse effects caused by neglecting the effects of local perturbations on specific stereogenic centers. Thus, the interpretation of our experimental ECD spectra is mainly based on empirical comparison and correlation to those of i) the dihydroflavonols taxifolin (15) and epitaxifolin (16) isolated from Thujopsis dolobrata [16] and ii) various benzodioxanes, e.g., the pair of benzodioxanes 17 and 18 synthesized from (+)-ephedrine; the natural benzodioxanes eusiderin (19) and eusiderin C (20) [17]; 21 and 22, isolated from Juniperus chinensis [18]; and benzodioxane $\mathbf{2 3}$ from Licaria chrysophylla [19] (Figure 5), for both the C-2, C-3 and C-10, C-11 pairs, respectively [20].

The ECD of the 3-hydroxyflavonone moiety was discussed with the aim to determine absolute configuration [21]. UV absorption bands in the respective $270-290 \mathrm{~nm}$ and $330-320 \mathrm{~nm}$ ranges were utilized, which were clearly rationalized in terms of the corresponding electronic transitions [22,23]. A pair of positive-negative CEs at both spectral ranges is characteristic of the $(2 R, 3 R)$ configuration of the 3-hydroxyflavonone moiety. Nevertheless, it should be kept in mind that there are also other absorption bands at shorter wavelengths giving rise to observable CEs near $230 \mathrm{~nm}$, which are relatively constant in pattern [24-28].

The ECD spectrum of compound 10: $\left(\theta\left[\mathrm{deg} \cdot \mathrm{cm}^{2} \cdot \mathrm{dmol}^{-1}\right]\right.$, CEs: $339 \mathrm{~nm}, \theta=+24971 ; 294 \mathrm{~nm}, \theta=-50028 ; 237 \mathrm{~nm} \theta=+16914$; $224 \mathrm{~nm}, \theta=-8082 ; 213 \mathrm{~nm}, \theta=-44628 ; 203 \mathrm{~nm}, \theta=+162457$; $193 \mathrm{~nm}, \theta=-71457$ ) (Figure S1, Supporting Information File 1) displayed the coupling constant $J_{2,3}=2.5 \mathrm{~Hz}$ corresponding to a cis-configuration and, therefore, compound $\mathbf{1 0}$ was assigned to the $2 R, 3 S$-isomer. The ECD spectrum of compound 9: $\left(\theta\left[\mathrm{deg} \cdot \mathrm{cm}^{2} \cdot \mathrm{dmol}^{-1}\right]\right.$, CEs: $338 \mathrm{~nm}, \theta=+26771 ; 292 \mathrm{~nm}$, $\theta=-60650 ; 233 \mathrm{~nm}, \theta=-58000 ; 214 \mathrm{~nm}, \theta=-9828 ; 207 \mathrm{~nm}$, 


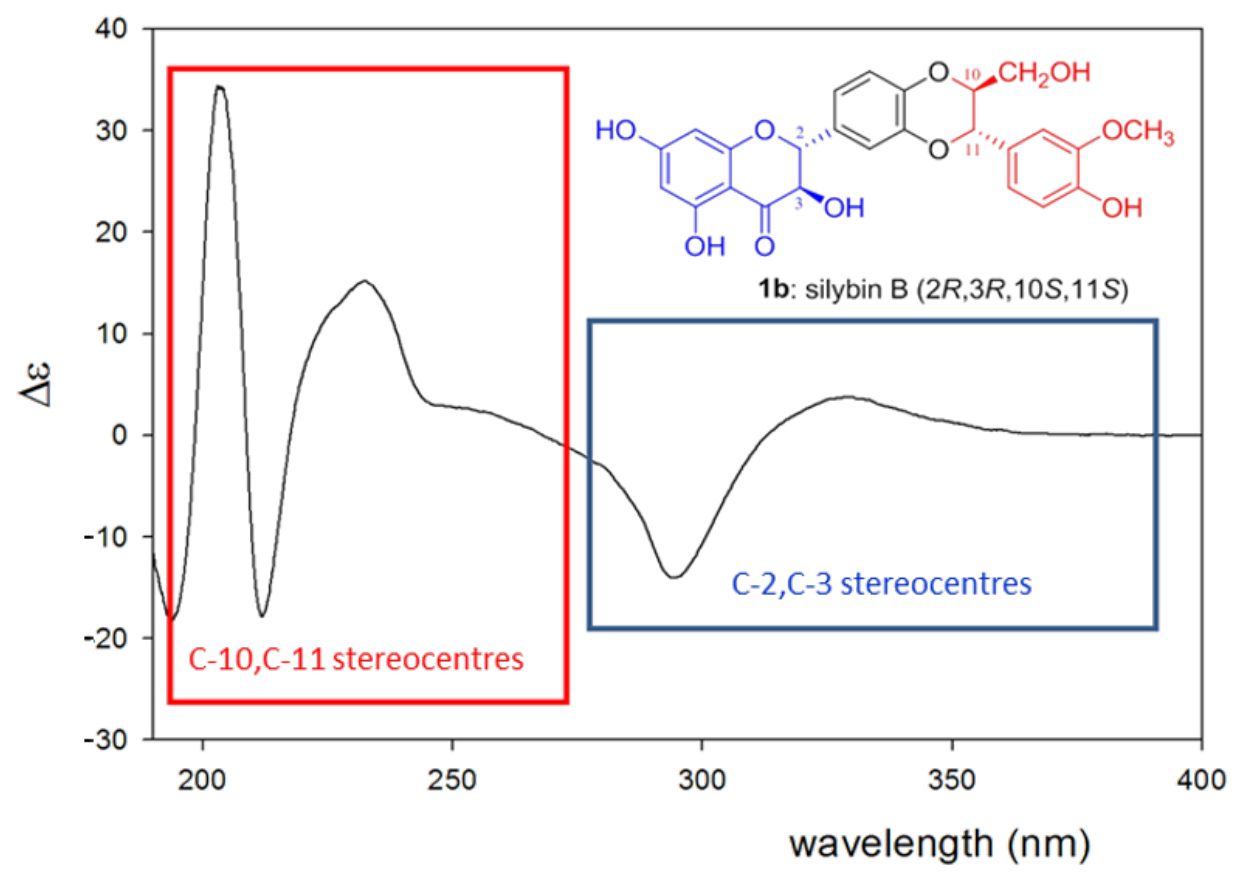

Figure 4: ECD spectrum of silybin B (1b) and its separation (in a crude approximation) into two m-conjugated moieties (3-hydroxyflavonone with stereogenic centers C-2, C-3 (in blue) and 1,4-benzodioxane with C-10,C-11) (in red) according to [2].<smiles>CC1(C)Oc2ccccc2OC1([AsH3])c1ccccc1</smiles>

17<smiles>[R16]C1Oc2c(OC)cc(CC=C)cc2OC1c1cc(OC)c(OC)c(OC)c1</smiles><smiles>COc1cc([C@H]2Oc3cc(CCCO)ccc3O[C@H]2CO)ccc1O</smiles>

21 (2S - trans) $22(2 R-c i s)$

Figure 5: Synthetic and natural (benzodioxane-type) compounds related to silybin stereoisomers with known absolute configurations.

$\theta=+83000 ; 197 \mathrm{~nm}, \theta=+77685$ ) (Figure S2, Supporting Information File 1) together with the $J_{2,3}$ coupling constant of $2.4 \mathrm{~Hz}$ (cis-configuration) are similar to (+)-epitaxifolin [16]. Therefore, the absolute configuration of 9 at $\mathrm{C}-2, \mathrm{C}-3$ is $2 R, 3 S$. The absolute configuration of compound $\mathbf{1 4}$ at $\mathrm{C}-2, \mathrm{C}-3$ is analo- gous to (+)-taxifolin $(2 R, 3 R)$, according to its $J_{2,3}$ value of $11.4 \mathrm{~Hz}$ and its ECD spectrum $\left(\mathbf{1 4}: \theta\left[\mathrm{deg} \cdot \mathrm{cm}^{2} \cdot \mathrm{dmol}^{-1}\right]\right.$, CEs: $327 \mathrm{~nm}, \theta=+9568 ; 293 \mathrm{~nm}, \theta=-46824 ; 240 \mathrm{~nm}$, $\Delta \varepsilon=+36917 \mathrm{deg} \cdot \mathrm{cm}^{2} \cdot \mathrm{dmol}^{-1} ; 230 \mathrm{~nm}, \theta=-8890 ; 211 \mathrm{~nm}$, $\theta=-63590$ ) (Figure S3, Supporting Information File 1). Accordingly, its absolute configuration at C-2, C-3 should be $2 R, 3 R$. Interestingly, compound $\mathbf{1 3}$ seems to be 2,3-trans-10,11cis-silybin according to its NMR spectra $\left(J_{2,3}=11.3 \mathrm{~Hz}\right.$, $\left.J_{10,11}=2.9 \mathrm{~Hz}\right)$. However, its ECD spectrum (13: $\theta\left[\mathrm{deg} \cdot \mathrm{cm}^{2} \cdot \mathrm{dmol}^{-1}\right]$, CEs: $328 \mathrm{~nm}, \theta=-12870 ; 294 \mathrm{~nm}$, $\theta=+44453 ; 253 \mathrm{~nm}, \theta=-7535 ; 242 \mathrm{~nm}, \theta=+7451 ; 229 \mathrm{~nm}$, $\theta=-71888 ; 205 \mathrm{~nm}, \theta=-1116600 ; 194 \mathrm{~nm}, \theta=+62990)$ (Figure S4, Supporting Information File 1) corresponds to (-)taxifolin. According to these results, the absolute configuration at $\mathrm{C}-2, \mathrm{C}-3$ is the opposite of the starting compound $\mathbf{1 a}(2 R, 3 R)$. Therefore, the absolute configuration of $\mathbf{1 3}$ is $2 S, 3 S$.

To assign the absolute configuration at $\mathrm{C}-10$ and $\mathrm{C}-11$ of silybin we combined the corresponding coupling constants $J_{10,11}$ with the CEs in 200-280 $\mathrm{nm}$ spectral range. It was shown that a sign of the CE at ca. $236 \mathrm{~nm}$ could be used to determine the stereochemistry at C-3 (i.e. C-10 of silybin) (negative CE corresponds to the $R$ configuration) $[2,17,20]$. Thus, the negative $\mathrm{CE}$ around $230 \mathrm{~nm}$ for $\mathbf{1 3}$, corroborated by the vicinal ${ }^{1} \mathrm{H}-{ }^{1} \mathrm{H}$ coupling constants $\left(J_{10,11}=2.9 \mathrm{~Hz}\right.$, e.g., cis-configuration $)$ (Figure S4, Supporting Information File 1) indicates an absolute configuration of $2 S, 3 S, 10 R, 11 S$. In contrast to the ECD spec- 
trum of silybin B (1b) (Figure S3, Supporting Information File 1$)$, the $J_{10,11}$ coupling constant $(2.8 \mathrm{~Hz}$, cis-configuration) of compound $\mathbf{1 4}$ and its ECD spectrum (positive/negative CE around $240 \mathrm{~nm}$ ) implies the absolute configuration at $\mathrm{C}-10$, $\mathrm{C}-11$ to be $10 S, 11 R$, so that the absolute configuration of $\mathbf{1 4}$ is $2 R, 3 R, 10 S, 11 R$.

The absolute configuration at C-10, C-11 of the 2,3-cis-10,11trans-silybins 9 and 10, as inferred from the coupling constants $\left(J_{10,11} \mathrm{ca} 8 \mathrm{~Hz}\right.$, trans-configuration) and the ECD spectra (Figure $\mathrm{S} 1$ and Figure S2, Supporting Information File 1), is $2 R, 3 S, 10 R, 11 R(\mathbf{9})$ and $2 R, 3 S, 10 S, 11 S(\mathbf{1 0})$. Here we would like to stress that the absolute configuration at C-10, C-11 of 9 and $\mathbf{1 0}$ remains the same as in the starting compounds, namely $\mathbf{1 a}$ $(10 R, 11 R)$ and $\mathbf{1 b}(10 S, 11 S)$, respectively.

\section{Mechanism of silybin isomerization}

Based on the absolute configuration of the new cis-silybin isomers, we propose mechanisms for the stereospecific isomerization.

The isomerization process is initiated by $\mathrm{BF}_{3}$ complexation. Boron trifluoride may complex silybin through a coordinate bond, in which the two electrons originate from the oxygen atoms of silybin. Silybin and $\mathrm{BF}_{3}$ are hard bases $(\eta=4.8 \mathrm{eV}$ in EtOAc) and acids $(\eta=7.3 \mathrm{eV}$ in EtOAc), respectively (Table 2), favoring such a coordinate bond. The hardness of $\mathrm{BF}_{3}$ and silybin $\mathrm{A}$ is not significantly modified when the solvent polarity is increased (Table 2). The hardness of silybin B was not calculated, as the stereochemistry is not expected to significantly modify this parameter. The hardness calculation is based on the HOMO (highest occupied molecular orbital) and LUMO (lowest unoccupied molecular orbital) energies, which are the same for silybin A and B. The quantum calculations show that the coordination complex at $\mathrm{C}-4=\mathrm{O}$ (IIa in Scheme 5) is the most stable (Table 3). The corresponding complex IIa exhibits a strong O-B bond of $1.55 \AA$, lower than, e.g., $1.73 \AA$ in the complex at O-1 (Table 4). In the benzopyranone moiety,
IIa is more stable than the complex at O- 1 by ca. $6 \mathrm{kcal} \cdot \mathrm{mol}^{-1}$. In the benzodioxane moiety, complexation at $\mathrm{O}-12$ is favored (compared to $\mathrm{O}-9$ ) by $4 \mathrm{kcal} \cdot \mathrm{mol}^{-1}$. The coordination with boron initiates isomerization at $\mathrm{C}-2, \mathrm{C}-3$ and $\mathrm{C}-10, \mathrm{C}-11$ by charge rearrangements (e.g., proton release and formation of IIb in Scheme 5). The mechanisms related to both sites can be considered separately, as both moieties are electronically independent.

Table 2: Chemical hardness $(\eta, e V)$ of $B_{3}$ and silybin $A(1 a)$, in three
different solvents (obtained at the IEFPCM B3P86/6-31+G(d,p) level of theory).

\begin{tabular}{lll}
\multirow{2}{*}{ solvent } & \multicolumn{2}{c}{$\eta$} \\
\cline { 2 - 3 } & $\mathrm{BF}_{3}$ & silybin A \\
\hline benzene & 7.4 & 4.7 \\
EtOAc & 7.3 & 4.8 \\
DMF & 7.0 & 4.8
\end{tabular}

Table 3: Electronic energies $\left(\Delta E, \mathrm{kcal} \cdot \mathrm{mol}^{-1}\right)$ of $\mathrm{BF}_{3}$ complexation with silybin $\mathrm{A}(1 \mathrm{a})$ at the different $\mathrm{O}$-atoms.

\begin{tabular}{lll} 
& EtOAc & DMF \\
\hline O-1 & -6.3 & -6.8 \\
C-4=0 & -12.4 & -12.8 \\
$0-9$ & -6.9 & -7.7 \\
$0-12$ & -10.9 & -11.3
\end{tabular}

The isomerization of flavanonols at C-2, C-3 is not without precedent, as it was described for taxillusin - the flavanonol glycoside from Taxillus kaempferi (Japanese mistletoe) containing the 3-hydroxy-2,3-dihydro-2-phenylchromen-4-one moiety [29]. Taxillusin (24, $(2 R, 3 R)$-taxifolin 3- $\beta$-D-glucopyranoside 6"-gallate, Figure 6) was subjected to both, basic and acidic hydrolysis during its structure elucidation. However, under these conditions four stereoisomers of the original

Table 4: Bond distance and atomic charge of interest in $\mathrm{BF}_{3}$-silybin $\mathrm{A}$ at $\mathrm{C}-4=\mathrm{O}$ (complex Ila) and $\mathrm{O}-1$, in a) EtOAc and b) DMF.

\begin{tabular}{lll} 
a) & complex at O-1 & complex at C-4=O (IIa) \\
\hline $\mathrm{d}(\mathrm{O}-\mathrm{B})$ & 1.734 & 1.557 \\
$\mathrm{~d}(\mathrm{O} 1-\mathrm{C} 2)$ & 1.485 & 1.441 \\
atomic charge at C3 & 0.023 & 0.030 \\
\hline b) & complex at O-1 & complex at C-4=O (IIa) \\
\hline $\mathrm{d}(\mathrm{O}-\mathrm{B})$ & 1.718 & 1.553 \\
$\mathrm{~d}(\mathrm{O} 1-\mathrm{C} 2)$ & 1.486 & 1.442 \\
atomic charge at C3 & 0.035 & 0.010
\end{tabular}


<smiles>[R]C1Oc2cc(O)cc(O)c2C(=O)C1([R])CC</smiles>

$2 a$<smiles>[R2]C1Oc2cc(O)cc(O)c2C(=O)[C@H]1O</smiles>

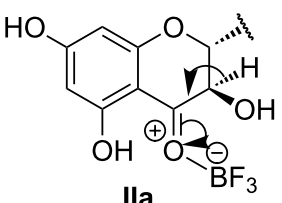

Ila

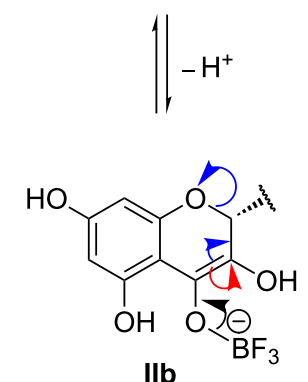<smiles>C=[PbH][PbH3]</smiles>
$+\mathrm{H}^{+}$<smiles>CC1(C)Oc2cc(O)cc(O)c2C(=O)[C@@H]1O</smiles>
+ compound $2 \mathrm{a}$

+ compound $2 \mathbf{a}$

Scheme 5: Proposed mechanisms of Lewis acid catalyzed isomerization at the benzopyranone ring of 23-O-acetylsilybin A (2a) in EtOAc.

aglycon $(2 R, 3 R)$-taxifolin were formed. Base-catalyzed isomerization of another taxifolin glycoside, $(2 R, 3 R)$-2,3-dihydroquercetin-3- $\alpha$-L-rhamnopyranoside (pyridine; aqueous solution), was reported earlier [30-33]. The thermal or enzymatic rearrangement of taxifolin to alphitonin yielded four taxifolin isomers [34]. With flavanonols (3-O-glycosides or the respective aglycons), isomerization can be explained by the benzopyranone ring enolization, which can be initiated by either acids or bases. A resonance effect can further cause reversible C-ring opening, thus allowing isomerization at C-2.<smiles>O=C(OCC1C(O)C(O)C(O)C(O)C(O)C1OC1C(=O)c2c(O)cc(O)cc2O[C@H]1c1ccc(O)c(O)c1)c1cc(O)c(O)c(O)c1</smiles>

Figure 6: Taxillusin, $(2 R, 3 R)$-taxifolin 3- $\beta$-D-glucopyranoside 6"-gallate (24).

The proposed mechanism for the isomerization of silybin at C-2, C-3 was inspired by these previous studies, i.e., involving an enolization stage (route II in Scheme 5) [29-34]. In EtOAc, the isomerization can occur from 1a or from its acetylated counterpart (2a), since the 23-O-acetylation proceeds in parallel with the isomerization and is substantially faster than the isomerization reaction.
In principle, the isomerization can be initiated by the formation of coordination complexes at either $\mathrm{C}-4=\mathrm{O}$ or $\mathrm{O}-1$ (see Scheme 5). Nevertheless, based on the quantum chemical calculations (Table 3 and Table 4) together with the representation of cis-isomers in the isomerization mixture, the most stable coordination complex IIa at $\mathrm{C}-4=\mathrm{O}$ is stabilized by a strong $\mathrm{O}-\mathrm{B}$ bond of $1.55 \AA$, having an atomic charge at C-3 close to zero (Table 4). This favors a proton release from this position and the formation of the negatively charged species IIb. The release of $\mathrm{BF}_{3}$ probably occurs from IIb by two different routes. The major pathway (route I) proceeds without ring opening and after re-protonation it leads to the major cis-isomer 12. The minor route (route II), accompanied by a ring opening of the benzopyranone, proceeds via intermediate IIc, which after ring closure and protonation yielded a mixture of $\mathbf{2 a}$ and $\mathbf{1 3}$. This reversible benzopyranone ring opening/closure process is probably responsible for the inversion of the absolute configuration at $\mathrm{C}-2$, C-3 of $\mathbf{1 3}$ compared to $\mathbf{2 a}$ (Scheme 5).

The limited degree of isomerization at $\mathrm{C}-2$ of silybin requiring the ring opening of the benzopyranone is in agreement with a related study of taxifolin isomerization [34]. A deuterium incorporation NMR study supported by quantum chemical calculations showed that the intermediate of taxifolin with an open benzopyranone ring ( $\alpha$-hydroxychalcone related to IIc in our study) is very short-lived and the energy barrier for its formation is relatively high [35]. It must be noted that IIc contains additional substitution at the ortho-dihydroxyphenol moiety, which probably further decreases the possibilities for resonance stabilization compared to unsubstituted $\alpha$-hydroxychalcone (quinone methide formation is disabled). 
Interestingly, the course of $\mathbf{1 a}$ and $\mathbf{1 b}$ isomerization was slightly different in DMF than in EtOAc, since it only yielded the cisisomers 9 and 10. The isomer with an inverted absolute configuration at C-2, C-3 (the non-acetylated form of 13) was not observed at all. This is easily explained by the charge distribution of complex IIa. In DMF, the atomic charge at C-3 is closer to zero than in EtOAc (Table 4). This clearly indicates that the formation of the open intermediates (IIc) is not supported in DMF.
The isomerization of $\mathbf{1}$ at the benzodioxane moiety is also initiated by $\mathrm{BF}_{3}$ complexation, followed by a multistep mechanism including the ring opening of benzodioxane. As the change in configuration takes place exclusively at $\mathrm{C}-11$, it is probably initiated by the acid-catalyzed dioxane ring opening at O-12 (Scheme 6). This site is highly nucleophilic in EtOAc (Figure 7a), with lone electron pairs, which is in favor of $\mathrm{BF}_{3}$ complexation as confirmed by the complexation energies (Table 3). Following complexation, the D-ring opening
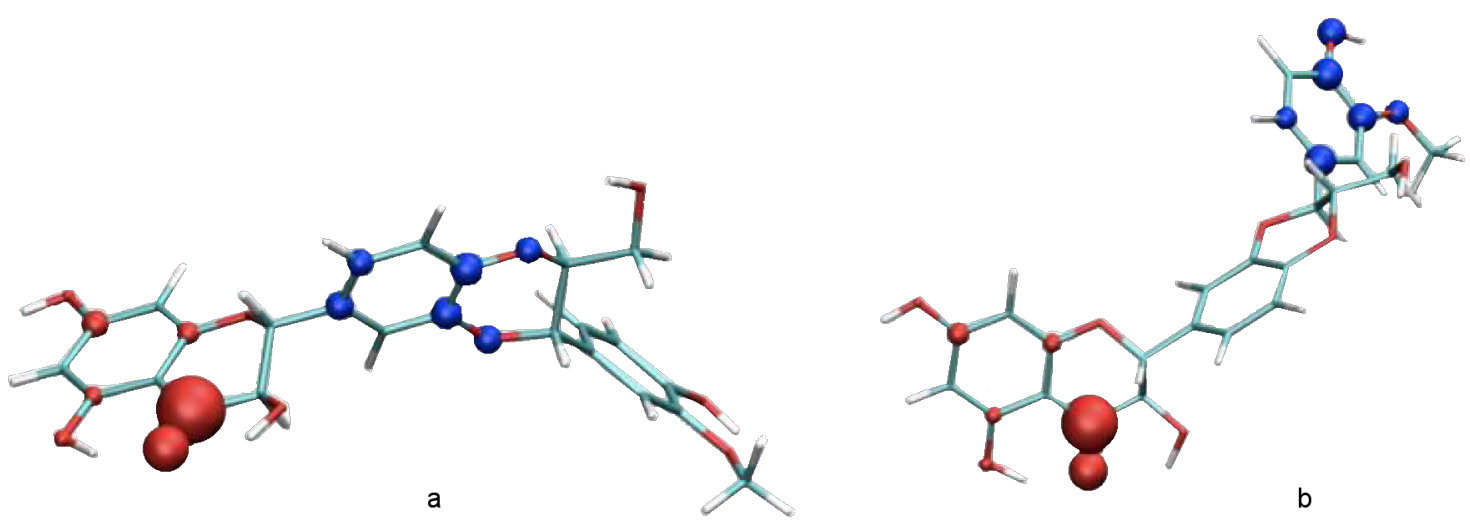

Figure 7: Spatial distribution of nucleophilic $f-(r)$ (blue) and electrophilic $f+(r)$ (blue) Fukui functions of silybin A (1a) in both a) EtOAc and b) DMF.<smiles>COc1cc([C@H]2Oc3ccc([C@@H]4Oc5cc(O)cc(O)c5C(=O)[C@H]4O)cc3O[C@@H]2CC(C)=O)ccc1O</smiles><smiles>CCO[SbH3+]</smiles><smiles>COc1cc([C@H]2OC(C)=C(C)O[C@@H]2COC(C)=O)ccc1O</smiles><smiles>C=C</smiles><smiles>COc1cc(C2Oc3ccc([C@@H]4Oc5cc(O)cc(O)c5C(=O)[C@H]4O)cc3O[C@H]2COC(C)=O)ccc1O</smiles><smiles>C1=CC=C1</smiles><smiles>COc1cc(C[C@@H](C)OC(C)=O)ccc1O</smiles>

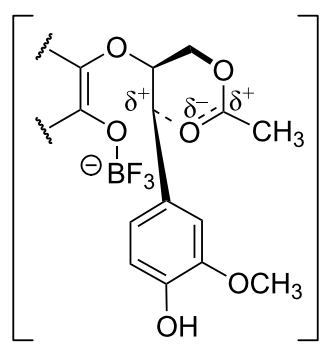

participation of acetyl group? 
proceeds (Scheme 6), allowing molecular rearrangements and isomerization after ring closure.

The observation of the isomerization of $\mathbf{1}$ (or 2) at C-11 that occurs in EtOAc but not in DMF can be explained either by a solvent effect or by the participation of the acetyl group. However, the second possibility is less probable, since the participation of the acetyl group should lead to the formation of an isomer with a retained configuration at C-11 (two subsequent nucleophilic substitutions with two Walden inversions). The possibility of acetyl group participation was refuted by the reaction of $\mathbf{2}$ in DMF, so that no isomerization took place at C-11. Moreover, in DMF the $f(\mathrm{r})$ Fukui function is totally displaced into the E-ring (Figure 7b), so that the O-12 atom loses its nucleophilic character, which partially rationalizes the solvent effect observed here.

\section{Conclusion}

We report here the first syntheses of hitherto undescribed cisisomers of silybin in optically pure form starting from silybin A (1a) and B (1b). The determination of their absolute configuration was based on an analysis of NMR coupling constants and a comparison of their ECD spectra with model compounds with well-defined absolute configurations. Moreover, the absolute configuration of these novel 2,3-cis- and 10,11-cis-isomers of silybin enabled us to propose mechanisms for the cis-trans isomerization of silybin. Although analogous isomerizations of similar compounds at respective C-2, C-3 centers have been described, we present here parallel isomerizations on both chiral centers under kinetic control. cis-Silybins were obtained by the chemoenzymatic separation methods mostly due to the sensitivity of new cis-derivatives to the reversed isomerization.

\section{Experimental}

\section{General experimental procedures}

NMR spectra were recorded in DMSO- $d_{6}\left(30{ }^{\circ} \mathrm{C}\right)$ by using a Bruker AVANCE $600 \mathrm{NMR}$ spectrometer $\left(600 \mathrm{MHz}\right.$ for ${ }^{1} \mathrm{H}$, $151 \mathrm{MHz}$ for ${ }^{13} \mathrm{C}$ ) with the residual solvent peak as the internal standard. Mass spectra were measured in an APEX-Ultra FTMS with ESI ionization. The high-resolution ESI-MS spectra were measured by using a GCT Premier benchtop orthogonal acceleration time-of-flight mass spectrometer.

Optical rotations were measured with a Rudolph Autopol polarimeter in acetone at $25^{\circ} \mathrm{C}$, and ECD spectra were recorded in a Jasco- 815 spectrometer in $\mathrm{MeOH}$ from 200 to $400 \mathrm{~nm}$ with a scanning speed $20 \mathrm{~nm} / \mathrm{min}$, time response $8 \mathrm{~s}$ with a $2 \mathrm{~mm}$ quartz cell and a sample concentration of ca. $1 \mathrm{mmol} / \mathrm{L}$.

HPLC analyses were carried out in a Shimadzu Prominence LC analytical system consisting of a Shimadzu LC-20AD binary
HPLC pump, Shimadzu SIL-20AC cooling autosampler, Shimadzu CTO-10AS column oven, and Shimadzu SPD-20MA diode array detector. The monolithic column was a Chromolith Performance, RP-18e, $100 \times 3 \mathrm{~mm}$ equipped with a guard column $(5 \times 4.6 \mathrm{~mm})$ with an isocratic mobile phase $\mathrm{CH}_{3} \mathrm{CN} /$

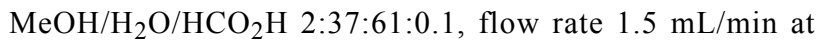
$25{ }^{\circ} \mathrm{C}$, detection at $285 \mathrm{~nm} ; t_{\mathrm{r}}($ silybin $\mathrm{A}, \mathbf{1 a})=3.1 \mathrm{~min}$, $t_{\mathrm{r}}(\operatorname{silybin} \mathrm{B}, \mathbf{1 b})=3.7 \mathrm{~min}, t_{\mathrm{r}}(23-O$-acetylsilybin $\mathrm{A})=$ $12.7 \mathrm{~min}, t_{\mathrm{r}}(23-O$-acetylsilybin $\mathrm{B}, \mathbf{2 b})=14.1 \mathrm{~min}$. For the semipreparatory HPLC, a chromolith SemiPrep RP-18e monolithic column, $100 \times 10 \mathrm{~mm}$ was used with an isocratic mobile phase $\mathrm{CH}_{3} \mathrm{OH} / \mathrm{H}_{2} \mathrm{O} 50: 50$. The flow rate was set to $5 \mathrm{~mL} / \mathrm{min}$ at $25^{\circ} \mathrm{C}$, the UV detection to $285 \mathrm{~nm} ; t_{\mathrm{r}}(\mathbf{2 a})=6.6 \mathrm{~min}, t_{\mathrm{r}}(\mathbf{1 3})=$ $7.8 \mathrm{~min}$.

\section{Materials}

Silybin (a mixture of diastereoisomers A (1a) and B (1b), ca. 1:1) was kindly provided by Dr. L. Cvak (division TAPI, Teva Czech Industries s.r.o., IVAX Pharmaceuticals, CZ). Silybin diastereoisomers were separated by lipase-catalyzed discrimination [5]. Candida antarctica lipase B (Novozym 435) was from Novozymes (DK). All other reagents were of analytical grade and used without further purification.

(2R,3S,10R,11R)-23-O-Acetylsilybin (12): $\mathrm{BF}_{3} \cdot \mathrm{OEt}_{2}(2 \mathrm{~mL}$, $15.926 \mathrm{mmol}, 50 \%$ solution in $\mathrm{OEt}_{2}$ ) was added to a stirred solution of $1 \mathrm{a}$ ( $2 \mathrm{~g}, 4.146 \mathrm{mmol},>99 \%$ optical purity) in DMF $(15 \mathrm{~mL})$ and further stirred for $1 \mathrm{~h}$ at $50{ }^{\circ} \mathrm{C}$. The reaction was quenched by the addition of an ice-cold solution of saturated $\mathrm{NaHCO}_{3}(100 \mathrm{~mL})$, extracted with EtOAc $(3 \times 50 \mathrm{~mL})$, the combined organic layers were dried $\left(\mathrm{Na}_{2} \mathrm{SO}_{4}\right)$ and evaporated. The residue was dissolved in $\mathrm{MeOH}(10 \mathrm{~mL})$ and a few drops of water were added. After several hours, the crystals formed were filtered off (ca. $1.1 \mathrm{~g}$, virtually pure trans-isomer) and the mother liquor was evaporated $(0.84 \mathrm{~g}$, ca. $30 \%$ of $c i s$-isomer, according to HPLC). The evaporated residue was then dissolved in a mixture of acetone/vinyl acetate $(100 \mathrm{~mL}, 9: 1, \mathrm{v} / \mathrm{v})$, Novozym 435 ( $0.84 \mathrm{~g}, \geq 10000 \mathrm{U} / \mathrm{g}, 100 \% \mathrm{w} / \mathrm{w})$ was added, and the mixture was shaken at $45{ }^{\circ} \mathrm{C}$ and $650 \mathrm{rpm}$ for $48 \mathrm{~h}$. After enzyme removal by filtration, the solution was evaporated and the crude mixture was purified by column chromatography $\left(\mathrm{CHCl}_{3} /\right.$ acetone $/ \mathrm{HCO}_{2} \mathrm{H}$ 95:5:1, twice $)$ yielding $\mathbf{2 a}(0.6 \mathrm{~g}, 30 \%$ yield, $>98 \%$ optical purity) and 12 (0.2 g, 10\% yield, $>97 \%$ optical purity). ${ }^{1} \mathrm{H}$ and ${ }^{13} \mathrm{C}$ NMR data see Table 5. HRMS (ESI-TOF) $m / z$ : $[\mathrm{M}-\mathrm{H}]^{-}$calcd for $\mathrm{C}_{27} \mathrm{H}_{23} \mathrm{O}_{11}, 523.1246$; found, 523.1245 .

(2R,3S,10S,11S)-23-O-Acetylsilybin (11) - Method A: This compound was prepared analogously to $\mathbf{1 2}$ starting from pure 1 b ( $2 \mathrm{~g}, 4.146 \mathrm{mmol},>99 \%$ optical purity) to yield $343 \mathrm{mg}$ of 11 (17\% yield, $>97 \%$ optical purity). ${ }^{1} \mathrm{H}$ and ${ }^{13} \mathrm{C}$ NMR data, see 
Table 5. HRMS (ESI-TOF) $m / z$ : $[\mathrm{M}-\mathrm{H}]^{-}$calcd for $\mathrm{C}_{27} \mathrm{H}_{23} \mathrm{O}_{11}$, 523.1246; found, 523.1247.

(2R,3S,10S,11S)-23-O-Acetylsilybin (11) - Method B: $\mathrm{BF}_{3} \cdot \mathrm{OEt}_{2}\left(2.3 \mathrm{~mL}, 18.3 \mathrm{mmol}, 50 \%\right.$ solution in $\left.\mathrm{OEt}_{2}\right)$ was added to a stirred solution of $\mathbf{1 b}$ ( $3 \mathrm{~g}, 6.2 \mathrm{mmol},>99 \%$ optical purity) in EtOAc $(100 \mathrm{~mL})$ and the mixture was stirred for $3 \mathrm{~h}$ at $80^{\circ} \mathrm{C}$. The reaction mixture was quenched by the addition of an ice-cold solution of saturated $\mathrm{NaHCO}_{3}(100 \mathrm{~mL})$, and after stirring for $10 \mathrm{~min}$ both phases were separated. The aqueous phase was extracted with EtOAc $(3 \times 50 \mathrm{~mL})$, the combined organic layers were dried $\left(\mathrm{Na}_{2} \mathrm{SO}_{4}\right)$ and evaporated. The residue after flash chromatography $\left(\mathrm{CHCl}_{3} /\right.$ acetone $/ \mathrm{HCO}_{2} \mathrm{H}$, 97:3:1, twice) yielded title compound 11 (50 mg, 2\% yield,
$>98 \%$ optical purity). ${ }^{1} \mathrm{H}$ and ${ }^{13} \mathrm{C}$ NMR data, see Table 5 . HRMS (ESI-TOF) $m / z$ : $[\mathrm{M}-\mathrm{H}]^{-}$calcd. for $\mathrm{C}_{27} \mathrm{H}_{23} \mathrm{O}_{11}$, 523.1246; found, 523.1246.

(2R,3S,10R,11R)-Silybin (9): Novozym 435 (1 g, $\geq 10000 \mathrm{U} / \mathrm{g})$ was added to a solution of $\mathbf{1 2}(200 \mathrm{mg}, 0.381 \mathrm{mmol})$ in a mixture of MTBE/n-butanol $(30 \mathrm{~mL}, 9: 1, \mathrm{v} / \mathrm{v})$, and the mixture was shaken at $45{ }^{\circ} \mathrm{C}$ and $650 \mathrm{rpm}$ for $100 \mathrm{~h}$. The enzyme was removed by filtration, the solution was evaporated, and the crude mixture purified by column chromatography $\left(\mathrm{CHCl}_{3} /\right.$ acetone $/ \mathrm{HCO}_{2} \mathrm{H}$ from 95:5:1 to 70:30:1) yielding title compound 9 (140 mg, 70\% yield, $>97 \%$ purity). ${ }^{1} \mathrm{H}$ and ${ }^{13} \mathrm{C} \mathrm{NMR}$ data, see Table 6 . $[\alpha]_{\mathrm{D}}{ }^{22}-51.6$ ( $c 0.091$, acetone); ECD spectrum, see Supporting Information File 1, Figure S2; HRMS

Table 5: NMR spectroscopic data $\left(600 \mathrm{MHz}, \mathrm{DMSO}-d_{6}, 30^{\circ} \mathrm{C}\right)$ of compounds 12 and 11.

\begin{tabular}{|c|c|c|c|c|c|c|}
\hline \multirow[b]{2}{*}{ position } & \multicolumn{3}{|c|}{$(2 R, 3 S, 10 R, 11 R)-23-O-a c e t y l s i l y b i n(12)$} & \multicolumn{3}{|c|}{$(2 R, 3 S, 10 S, 11 S)-23-O-a c e t y l s i l y b i n(11)$} \\
\hline & $\delta_{C}$ & $m^{a}$ & $\delta_{H}(m, J$ in $H z)$ & $\delta_{C}$ & $m^{a}$ & $\delta_{H}(m, J$ in $H z)$ \\
\hline 2 & 80.50 & $d$ & $5.460(\mathrm{~d}, 2.4)$ & 80.52 & $d$ & $5.461(\mathrm{~d}, 2.4)$ \\
\hline 3 & 70.78 & $d$ & 4.109 (br.d, $2.4,6.4)$ & 70.79 & $d$ & $4.113(\mathrm{dd}, 2.4,6.4)$ \\
\hline 4 & 195.29 & $\mathrm{~s}$ & - & 195.31 & $\mathrm{~s}$ & - \\
\hline $4 a$ & 100.27 & s & - & 100.29 & s & - \\
\hline 5 & 164.00 & $\mathrm{~s}$ & - & 164.01 & $\mathrm{~s}$ & - \\
\hline 6 & 96.04 & $d$ & $5.908(\mathrm{~d}, 2.1)$ & 96.05 & $d$ & $5.912(\mathrm{~d}, 2.1)$ \\
\hline 7 & 166.86 & $\mathrm{~s}$ & - & 166.85 & $s$ & - \\
\hline 8 & 95.05 & $d$ & $5.936(\mathrm{~d}, 2.1)$ & 95.05 & $d$ & $5.940(\mathrm{~d}, 2.1)$ \\
\hline $8 a$ & 162.49 & $\mathrm{~s}$ & - & 162.50 & $\mathrm{~s}$ & - \\
\hline 10 & 75.01 & $d$ & 4.491 (ddd, 8.0, 5.2, 2.7) & 75.02 & $d$ & $4.492(\mathrm{ddd}, 7.9,5.2,2.7)$ \\
\hline 11 & 75.85 & $d$ & $4.913(\mathrm{~d}, 8.0)$ & 75.86 & $d$ & $4.915(\mathrm{~d}, 7.9)$ \\
\hline $12 a$ & 143.06 & $\mathrm{~s}$ & - & 143.07 & $\mathrm{~s}$ & - \\
\hline 13 & 116.26 & d & $7.080(\mathrm{~d}, 2.0)$ & 116.27 & d & $7.083(d, 2.0)$ \\
\hline 14 & 129.51 & $\mathrm{~s}$ & - & 129.52 & $\mathrm{~s}$ & - \\
\hline 15 & 120.70 & $d$ & $7.020(\mathrm{dd}, 8.4,2.0)$ & 120.70 & $d$ & $7.022(\mathrm{dd}, 8.3,2.0)$ \\
\hline 16 & 116.30 & $d$ & $6.976(\mathrm{~d}, 8.4)$ & 116.31 & $d$ & $6.978(\mathrm{~d}, 8.3)$ \\
\hline $16 a$ & 142.59 & $\mathrm{~s}$ & - & 142.60 & $\mathrm{~s}$ & - \\
\hline 17 & 126.67 & $\mathrm{~s}$ & - & 126.68 & $\mathrm{~s}$ & - \\
\hline 18 & 111.74 & $d$ & $7.013(\mathrm{~d}, 1.9)$ & 111.74 & $d$ & $7.014(\mathrm{~d}, 2.0)$ \\
\hline 19 & 147.80 & $\mathrm{~s}$ & - & 147.81 & s & - \\
\hline 20 & 147.34 & $\mathrm{~s}$ & - & 147.34 & $\mathrm{~s}$ & - \\
\hline 21 & 115.50 & $d$ & $6.809(\mathrm{~d}, 8.0)$ & 115.51 & $d$ & $6.812(\mathrm{~d}, 8.0)$ \\
\hline 22 & 120.60 & $d$ & $6.861(\mathrm{dd}, 8.0,1.9)$ & 120.61 & d & $6.863(\mathrm{dd}, 2.0,8.0)$ \\
\hline \multirow[t]{2}{*}{23} & 62.65 & $\mathrm{t}$ & $4.081(\mathrm{dd}, 2.7,12.4)$ & 62.66 & $\mathrm{~m}$ & $4.084(\mathrm{dd}, 2.7,12.4)$ \\
\hline & & & $3.926(\mathrm{dd}, 5.2,12.4)$ & & $d$ & $3.928(\mathrm{dd}, 5.2,12.4)$ \\
\hline $3-\mathrm{OH}$ & - & - & $6.223(d, 6.4)$ & - & $d$ & $6.227(\mathrm{~d}, 6.4)$ \\
\hline $5-\mathrm{OH}$ & - & - & $11.861(\mathrm{~s})$ & - & $\mathrm{s}$ & $11.863(\mathrm{~s})$ \\
\hline $7-\mathrm{OH}$ & - & - & 10.805 (br s) & - & $\mathrm{s}$ & $10.813(\mathrm{br} \mathrm{s})$ \\
\hline 19-OMe & 55.75 & $q$ & $3.773(\mathrm{~s})$ & 55.75 & $\mathrm{~s}$ & $3.775(\mathrm{~s})$ \\
\hline $20-\mathrm{OH}$ & - & - & $9.164(\mathrm{~s})$ & - & $d$ & $9.167(\mathrm{~s})$ \\
\hline $23-C=O$ & 170.06 & $\mathrm{~s}$ & - & 170.07 & $\mathrm{~s}$ & - \\
\hline $23-A c$ & 20.46 & $q$ & $2.021(\mathrm{~s})$ & 20.47 & $\mathrm{~m}$ & $2.022(\mathrm{~s})$ \\
\hline
\end{tabular}

${ }^{a}$ multiplicity of ${ }^{13} \mathrm{C}$ signals. 
Table 6: NMR spectroscopic data (600 MHz, DMSO- $\left.d_{6}, 30{ }^{\circ} \mathrm{C}\right)$ of compounds 9 and 10.

$(2 R, 3 S, 10 R, 11 R)$-silybin (9)

$(2 R, 3 S, 10 S, 11 S)$-silybin (10)

\begin{tabular}{|c|c|c|c|c|c|c|}
\hline position & $\delta_{C}$ & $\mathrm{~m}^{\mathrm{a}}$ & $\delta_{H}(m, J$ in $H z)$ & $\delta_{C}$ & $m^{a}$ & $\delta_{H}(m, J$ in $H z)$ \\
\hline 2 & 80.60 & $d$ & $5.441(\mathrm{ddd}, 2.4,0.7,0.6)$ & 80.60 & $d$ & $5.443(\mathrm{ddd}, 2.5,0.6,0.4)$ \\
\hline 3 & 70.81 & $\mathrm{~d}$ & 4.092 (br.d, 2.4) & 70.82 & $d$ & $4.087(\mathrm{~m},-)$ \\
\hline 4 & 195.21 & $\mathrm{~s}$ & - & 195.25 & $\mathrm{~s}$ & - \\
\hline $4 a$ & 100.17 & $\mathrm{~s}$ & - & 100.22 & $\mathrm{~s}$ & - \\
\hline 5 & 164.03 & $\mathrm{~s}$ & - & 164.04 & $\mathrm{~s}$ & - \\
\hline 6 & 96.08 & $d$ & $5.897(\mathrm{~d}, 2.1)$ & 96.07 & $d$ & $5.903(\mathrm{~d}, 2.1)$ \\
\hline 7 & 167.15 & $\mathrm{~s}$ & - & 167.04 & $\mathrm{~s}$ & - \\
\hline 8 & 95.09 & $d$ & $5.925(d, 2.1)$ & 95.08 & $d$ & $5.934(\mathrm{~d}, 2.1)$ \\
\hline $8 a$ & 162.54 & $\mathrm{~s}$ & - & 162.57 & $\mathrm{~s}$ & - \\
\hline 10 & 78.14 & $d$ & $4.151(\mathrm{ddd}, 7.9,4.7,2.5)$ & 78.15 & $d$ & $4.144(\mathrm{ddd}, 7.8,4.7,2.6)$ \\
\hline 11 & 75.86 & $d$ & $4.889(\mathrm{~d}, 7.9)$ & 75.90 & $d$ & $4.891(\mathrm{~d}, 7.8)$ \\
\hline $12 a$ & 143.11 & $\mathrm{~s}$ & - & 143.21 & $\mathrm{~s}$ & - \\
\hline 13 & 116.14 & $d$ & $7.055(\mathrm{dd}, 2.0,0.7)$ & 116.15 & $d$ & $7.052(\mathrm{dd}, 2.0,0.4)$ \\
\hline 14 & 129.09 & $\mathrm{~s}$ & - & 129.07 & $\mathrm{~s}$ & - \\
\hline 15 & 120.46 & $d$ & $6.998(\mathrm{ddd}, 8.3,2.0,0.6)$ & 120.47 & $d$ & 7.001 (ddd, 8.3, 2.0, 0.6) \\
\hline 16 & 116.18 & $d$ & $6.945(d, 8.3)$ & 116.19 & $d$ & $6.947(\mathrm{~d}, 8.3)$ \\
\hline $16 a$ & 143.19 & $\mathrm{~s}$ & - & 143.11 & $\mathrm{~s}$ & - \\
\hline 17 & 127.56 & $\mathrm{~s}$ & - & 127.57 & $\mathrm{~s}$ & - \\
\hline 18 & 111.76 & $d$ & $7.002(\mathrm{~d}, 2.0)$ & 111.79 & $d$ & $7.003(\mathrm{~d}, 1.9)$ \\
\hline 19 & 147.67 & $\mathrm{~s}$ & - & 147.68 & $\mathrm{~s}$ & - \\
\hline 20 & 147.06 & $\mathrm{~s}$ & - & 147.07 & $\mathrm{~s}$ & - \\
\hline 21 & 115.37 & $d$ & $6.802(\mathrm{~d}, 8.1)$ & 115.38 & $d$ & $6.803(\mathrm{~d}, 8.1)$ \\
\hline 22 & 120.54 & $d$ & $6.858(\mathrm{dd}, 8.1,2.0)$ & 120.55 & $d$ & $6.860(\mathrm{dd}, 1.9,8.1)$ \\
\hline \multirow[t]{2}{*}{23} & 60.23 & $\mathrm{t}$ & $3.534(\mathrm{dd}, 2.5,12.2)$ & 60.24 & $\mathrm{t}$ & $3.532(\mathrm{~m})$ \\
\hline & & & $3.341(\mathrm{dd}, 4.7,12.2)$ & & & $3.340(\mathrm{~m})$ \\
\hline $3-\mathrm{OH}$ & - & - & 6.216 (br.s) & & - & 6.212 (br.d, 5.5) \\
\hline $5-\mathrm{OH}$ & - & - & 11.884 (br.s) & & - & $11.881(\mathrm{~s})$ \\
\hline 7-OH & - & - & n.d. & & - & n.d. \\
\hline 19-OMe & 55.75 & $q$ & 3.777 (s) & 55.76 & $q$ & $3.780(\mathrm{~s})$ \\
\hline $20-\mathrm{OH}$ & - & - & 9.151 (br.s) & & - & 9.118 (br.s) \\
\hline 23-OH & - & - & & & $d$ & \\
\hline
\end{tabular}

amultiplicity of ${ }^{13} \mathrm{C}$ signals.

(ESI-TOF) $m / z:[\mathrm{M}+\mathrm{H}]^{+}$calcd for $\mathrm{C}_{25} \mathrm{H}_{23} \mathrm{O}_{10}, 483.1291$; found, 483.1296 .

$(2 R, 3 S, 10 S, 11 S)-S i l y b i n(10):$ This compound was prepared analogously to 9 starting from pure 11 (343 $\mathrm{mg}, 0.654 \mathrm{mmol}$ ) to yield 8 (220 mg, 64\% yield, $>96 \%$ purity). ${ }^{1} \mathrm{H}$ and ${ }^{13} \mathrm{C}$ NMR data, see Table $6 .[\alpha]_{\mathrm{D}}{ }^{22}-40.4$ (c 0.39 , acetone); ECD spectrum, see Supporting Information File 1, Figure S1; HRMS (ESI-TOF) $m / z:[\mathrm{M}+\mathrm{H}]^{+}$calcd. for $\mathrm{C}_{25} \mathrm{H}_{23} \mathrm{O}_{10}, 483.1291$; found, 483.1294.

(2R,3R,10S,11R)-23-O-Acetylsilybin (8): $\mathrm{BF}_{3} \cdot \mathrm{OEt}_{2}(1.5 \mathrm{~mL}$, $12.2 \mathrm{mmol}, 50 \%$ solution in $\mathrm{OEt}_{2}$ ) was added to a stirred solution of $\mathbf{1 b}$ ( $2 \mathrm{~g}, 4.1 \mathrm{mmol},>99 \%$ optical purity) in EtOAc
$(100 \mathrm{~mL})$ and the mixture was kept for $48 \mathrm{~h}$ at $80^{\circ} \mathrm{C}$. The reaction mixture was quenched by the addition of an ice-cold solution of saturated $\mathrm{NaHCO}_{3}(100 \mathrm{~mL})$, and after stirring for $10 \mathrm{~min}$ both phases were separated. The aqueous phase was extracted with EtOAc $(3 \times 50 \mathrm{~mL})$. The combined organic layers were dried $\left(\mathrm{Na}_{2} \mathrm{SO}_{4}\right)$ and evaporated to dryness. The crude mixture was purified by column chromatography $\left(\mathrm{CHCl}_{3} /\right.$ acetone/toluene/ $\mathrm{HCO}_{2} \mathrm{H}, 95: 5: 5: 1$, twice) yielding a mixture of 2b and 8, which was then dissolved in a mixture of MTBE $/ n$ butanol (150 mL, 9:1 v/v), Novozym 435 (0.25 g, $\geq 10000 \mathrm{U} / \mathrm{g}$, $100 \% \mathrm{w} / \mathrm{w}$ ) was added, and the mixture was shaken at $45{ }^{\circ} \mathrm{C}$ and $650 \mathrm{rpm}$ for $37 \mathrm{~h}$ until the ratio of $\mathbf{8} / \mathbf{2 b}$ was $96: 4$ (HPLC). After enzyme removal by filtration, the solution was evaporated, and the crude mixture purified by column chromatog- 
raphy $\left(\mathrm{CHCl}_{3} /\right.$ acetone $/ \mathrm{HCO}_{2} \mathrm{H}$ 90:10:1) yielding $\mathbf{1 b}(0.898 \mathrm{~g}$, 45\% yield, >99\% purity) and 12 (0.06 g, 3\% yield, >98\% purity). ${ }^{1} \mathrm{H}$ and ${ }^{13} \mathrm{C}$ NMR data, see Table 7. HRMS (ESI-TOF) $m / z$ : $[\mathrm{M}-\mathrm{H}]^{-}$calcd for $\mathrm{C}_{27} \mathrm{H}_{23} \mathrm{O}_{11}, 523.1246$; found, 523.1244 .

(2S,3S,10R,11S)-23-O-Acetylsilybin (13): $\mathrm{BF}_{3} \cdot \mathrm{OEt}_{2}(2.7 \mathrm{~mL}$, $21.9 \mathrm{mmol}, 50 \%$ solution in $\mathrm{OEt}_{2}$ ) was added to a stirred solution of $1 \mathrm{a}(2.7 \mathrm{~g}, 5.6 \mathrm{mmol},>99 \%$ optical purity) in EtOAc $(30 \mathrm{~mL})$ and the mixture was kept at $80{ }^{\circ} \mathrm{C}$ for $48 \mathrm{~h}$. The reaction mixture was quenched by the addition of an ice-cold solution of saturated $\mathrm{NaHCO}_{3}(100 \mathrm{~mL})$, and after stirring for $10 \mathrm{~min}$ both phases were separated. The aqueous phase was extracted with EtOAc $(3 \times 50 \mathrm{~mL})$, the combined organic layers were dried $\left(\mathrm{Na}_{2} \mathrm{SO}_{4}\right)$ and evaporated. The crude mixture was purified by column chromatography $\left(\mathrm{CHCl}_{3} /\right.$ acetone $/ \mathrm{HCO}_{2} \mathrm{H}$ 95:5:1, twice), yielding 12 ( $0.32 \mathrm{~g} ; 12 \%,>96 \%$ purity) and a mixture of $\mathbf{2 a}$ and 13. After evaporation of the solvent, the residue containing compounds $\mathbf{2 a}$ and $\mathbf{1 3}(1 \mathrm{~g})$ was then dissolved in a mixture of MTBE/ $n$-butanol $(30 \mathrm{~mL}, 9: 1, \mathrm{v} / \mathrm{v})$, Novozym 435 ( $0.3 \mathrm{~g}, \geq 10000 \mathrm{U} / \mathrm{g}, 30 \% \mathrm{w} / \mathrm{w})$ was added and the mixture was shaken at $45{ }^{\circ} \mathrm{C}$ and $650 \mathrm{rpm}$ for $72 \mathrm{~h}$ to give a 13/2a ratio of ca. 2:3 (HPLC). After enzyme removal by filtration, the solution was evaporated, and the crude mixture was purified by column chromatography $\left(\mathrm{CHCl}_{3} /\right.$ acetone $/ \mathrm{HCO}_{2} \mathrm{H}$ 90:10:1) to remove 1a. Subsequent preparative HPLC separation (A Chromolith SemiPrep RP-18e monolithic column, $100 \times 10 \mathrm{~mm}$, Merck) of the mixture of $\mathbf{2 a}$ and $\mathbf{1 3}$ was carried

Table 7: NMR spectroscopic data $\left(600 \mathrm{MHz}, \mathrm{DMSO}-d_{6}, 30^{\circ} \mathrm{C}\right)$ of compounds 8 and 13

$(2 R, 3 R, 10 S, 11 R)-23-O-a c e t y l s i l y b i n(8)$

\begin{tabular}{|c|c|c|c|c|c|c|}
\hline position & $\delta_{C}$ & $\mathrm{~m}^{\mathrm{a}}$ & $\delta_{H}(m, J$ in $H z)$ & $\delta_{C}$ & $\mathrm{~m}^{\mathrm{a}}$ & $\delta_{H}(m, J$ in $H z)$ \\
\hline 2 & 82.48 & $d$ & $5.101(d, 11.4)$ & 82.44 & d & $5.085(\mathrm{dd}, 0.4,11.3)$ \\
\hline 3 & 71.46 & $d$ & $4.618(\mathrm{dd}, 6.1,11.4)$ & 71.46 & d & $4.597(\mathrm{dd}, 6.3,11.3)$ \\
\hline 4 & 197.71 & $\mathrm{~s}$ & - & 197.32 & $\mathrm{~s}$ & - \\
\hline $4 a$ & 100.48 & $\mathrm{~s}$ & - & 100.21 & $\mathrm{~s}$ & - \\
\hline 5 & 163.32 & $\mathrm{~s}$ & - & 163.36 & $\mathrm{~s}$ & - \\
\hline 6 & 96.13 & $d$ & $5.923(\mathrm{~d}, 2.1)$ & 96.31 & $d$ & 5.879 (br.s, -) \\
\hline 7 & 166.86 & $\mathrm{~s}$ & - & 167.00 & $\mathrm{~s}$ & - \\
\hline 8 & 95.07 & $d$ & $5.883(\mathrm{~d}, 2.1)$ & 95.31 & $d$ & 5.848 (br.s, -) \\
\hline $8 a$ & 162.48 & $\mathrm{~s}$ & - & 162.44 & $\mathrm{~s}$ & - \\
\hline 10 & 73.83 & $d$ & 4.801 (ddd, $2.8,3.4,8.2)$ & 73.87 & $d$ & $4.793(\mathrm{ddd}, 2.9,3.4,8.3)$ \\
\hline 11 & 74.60 & $d$ & $5.340(\mathrm{dd}, 0.6,2.8)$ & 74.60 & $d$ & $5.337(\mathrm{ddd}, 0.4,0.7,2.9)$ \\
\hline $12 a$ & 142.43 & $\mathrm{~s}$ & - & 142.47 & $\mathrm{~s}$ & - \\
\hline 13 & 116.95 & $d$ & $7.167(\mathrm{~d}, 2.0)$ & 116.87 & $d$ & $7.171(\mathrm{~d}, 2.0)$ \\
\hline 14 & 130.86 & $\mathrm{~s}$ & - & 130.95 & $\mathrm{~s}$ & - \\
\hline 15 & 121.79 & $d$ & $7.066(\mathrm{dd}, 2.0,8.3)$ & 121.97 & d & $7.049(\mathrm{ddd}, 0.4,2.0,8.3)$ \\
\hline 16 & 116.92 & $d$ & $7.013(\mathrm{~d}, 8.3)$ & 116.93 & $d$ & $7.005(\mathrm{~d}, 8.3)$ \\
\hline $16 a$ & 141.73 & $\mathrm{~s}$ & - & 141.70 & $\mathrm{~s}$ & - \\
\hline 17 & 126.52 & $\mathrm{~s}$ & - & 126.53 & $\mathrm{~s}$ & - \\
\hline 18 & 110.73 & $d$ & $7.023(\mathrm{~d}, 2.0)$ & 110.65 & $d$ & $7.026(\mathrm{dd}, 0.4,2.1)$ \\
\hline 19 & 147.62 & $\mathrm{~s}$ & - & 147.63 & $\mathrm{~s}$ & - \\
\hline 20 & 146.65 & $\mathrm{~s}$ & - & 146.65 & $\mathrm{~s}$ & - \\
\hline 21 & 115.59 & $d$ & $6.811(\mathrm{~d}, 8.2)$ & 115.59 & $d$ & $6.807(d, 8.1)$ \\
\hline 22 & 118.67 & $d$ & $6.860(\mathrm{ddd}, 0.6,2.0,8.2)$ & 118.66 & $d$ & $6.859(\mathrm{ddd}, 0.7,2.1,8.1)$ \\
\hline \multirow[t]{2}{*}{23} & 60.38 & $\mathrm{t}$ & $4.004(\mathrm{dd}, 3.4,12.2)$ & 55.73 & $\mathrm{t}$ & $3.998(\mathrm{dd}, 3.4,12.2)$ \\
\hline & & & $3.954(\mathrm{dd}, 8.2,12.2)$ & & & $3.995(\mathrm{dd}, 8.3,12.2)$ \\
\hline $3-\mathrm{OH}$ & - & - & $5.783(d, 6.1)$ & - & & $5.769(\mathrm{~d}, 6.3)$ \\
\hline $5-\mathrm{OH}$ & - & - & $11.875(\mathrm{~s})$ & - & & $11.902(\mathrm{~s},-)$ \\
\hline $7-\mathrm{OH}$ & - & - & 10.788 (br s) & - & & 10.860 (br.s, -) \\
\hline 19-OMe & 55.73 & $q$ & $3.757(\mathrm{~s})$ & 55.73 & $q$ & $3.757(\mathrm{~s},-)$ \\
\hline $20-\mathrm{OH}$ & - & - & $9.093(\mathrm{~s})$ & - & & $9.119(\mathrm{~s},-)$ \\
\hline $23-\mathrm{CO}$ & 170.08 & $\mathrm{~s}$ & - & 170.13 & $\mathrm{~s}$ & - \\
\hline 23-Ac & 20.46 & $q$ & 1.941 (s) & 20.51 & $q$ & $1.940(\mathrm{~s},-)$ \\
\hline
\end{tabular}

amultiplicity of ${ }^{13} \mathrm{C}$ signals. 
out with an isocratic mobile phase $\mathrm{CH}_{3} \mathrm{OH} / \mathrm{H}_{2} \mathrm{O}$ 50:50, a flow rate of $5 \mathrm{~mL} / \mathrm{min}$ at $25^{\circ} \mathrm{C}$, and $\mathrm{UV}$ detection at $285 \mathrm{~nm} ; t_{\mathrm{r}}$ (2a) $=6.6 \mathrm{~min}, t_{\mathrm{r}}(\mathbf{1 3})=7.8 \mathrm{~min}$.) yielding $2 \mathbf{a}(20 \mathrm{mg}, 0.7 \%$ yield, $>98 \%$ purity) and $13(7 \mathrm{mg}, 0.3 \%$ yield, $>96 \%$ purity $) .[\alpha]_{\mathrm{D}}{ }^{22}$ +69.7 (c 0.11, acetone); ECD spectrum, see Supporting Information File 1, Figure $\mathrm{S} 4 ;{ }^{1} \mathrm{H}$ and ${ }^{13} \mathrm{C}$ NMR data, see Table 7; HRMS (ESI-TOF) $m / z$ : $[\mathrm{M}+\mathrm{Na}]^{+}$calcd for $\mathrm{C}_{27} \mathrm{H}_{24} \mathrm{O}_{11} \mathrm{Na}$, 547.1211; found, 547.1209.

(2R,3R,10S,11R)-Silybin (14): Novozym $435(0.350 \mathrm{~g}, 500 \%$ $\mathrm{w} / \mathrm{w}, \geq 10000 \mathrm{U} / \mathrm{g})$ was added to $12(60 \mathrm{mg}, 0.11 \mathrm{mmol})$ dissolved in a mixture of MTBE/ $n$-butanol $(15 \mathrm{~mL}, 9: 1, \mathrm{v} / \mathrm{v})$, and the mixture was shaken at $45^{\circ} \mathrm{C}$ and $650 \mathrm{rpm}$ for $120 \mathrm{~h}$. The enzyme was then filtered off, the solution evaporated, and the crude mixture purified by column chromatography $\left(\mathrm{CHCl}_{3} /\right.$ acetone $/ \mathrm{HCO}_{2} \mathrm{H}$ from $97: 3: 1$ to $\left.70: 30: 1\right)$ yielding title compound 14 (40 mg, $67 \%$ yield, $>98 \%$ purity). $[\alpha]_{\mathrm{D}}^{22}-59.2(c$ 0.13 , acetone); ECD spectrum, see Supporting Information File 1, Figure $\mathrm{S} 3 ;{ }^{1} \mathrm{H}$ and ${ }^{13} \mathrm{C}$ NMR data, see Table 8; HRMS (ESI-TOF) $m / z$ : $[\mathrm{M}+\mathrm{H}]^{+}$calcd for $\mathrm{C}_{25} \mathrm{H}_{23} \mathrm{O}_{10}, 483.1291$; found, 483.1289

\section{Calculation methods}

All geometries and energies, including the zero-point correction (V), enthalpies $(H)$ and Gibbs energies $(G)$ at $298 \mathrm{~K}$ of the reactants, intermediates and products were determined at the (U)B3P86/6-31+G(d,p) level, well-adapted for polyphenol reactivity. Solvent effects were implicitly taken into account by using a PCM (polarizable continuum model) method; the IEFPCM (integral equation formalism PCM) method coupled to UA0 radii was used. The mechanisms were studied with both EtOAc and DMF solvents with a dielectric constant $\varepsilon$ of 5.99 and 37.21 , respectively.

The hardness $\eta$ is related to the hard-soft-acid-basis (HSAB) principle. According to this theory, hard acids react with hard bases whereas soft acids react with soft bases. The hardness is given by $\eta=\frac{I-A}{2}$ where $I$ and $A$ are the adiabatic ionization potential and the adiabatic electron affinity, respectively. The hardness of silybin B was not calculated, as the stereochemistry is not expected to significantly modify this parameter. The hardness calculation is based on the HOMO (highest occupied molecular orbiral) and LUMO (lowest occupied molecular orbital) energies, which are the identical for silybin A and B. The hardness was calculated in benzene, EtOAc, and DMF to study the impact of the solvent polarity on the HSAB principle. The hardness of $\mathrm{BF}_{3}$ and silybin $\mathrm{A}$ is not significantly modified when the solvent polarity is increased (Table 2).

New methods to rationalize chemical reactivity have been developed in the field of quantum mechanical methods over the
Table 8: NMR spectroscopic data $\left(600 \mathrm{MHz}\right.$, DMSO- $\left.d_{6}, 30^{\circ} \mathrm{C}\right)$ of compound 14.

$(2 R, 3 R, 10 S, 11 R)$-silybin (14)

\begin{tabular}{|c|c|c|c|}
\hline position & $\delta_{C}[p p m]$ & $\mathrm{m}^{\mathrm{a}}$ & $\delta_{H}(m, J$ in $H z)$ \\
\hline 2 & 82.56 & $d$ & $5.082(\mathrm{dd}, 0.4,11.4)$ \\
\hline 3 & 71.44 & $d$ & $4.608(\mathrm{dd}, 5.8,11.4)$ \\
\hline 4 & 197.69 & s & - \\
\hline $4 a$ & 100.43 & s & - \\
\hline 5 & 163.30 & s & - \\
\hline 6 & 96.12 & $d$ & $5.913(\mathrm{~d}, 2.1)$ \\
\hline 7 & 166.94 & s & - \\
\hline 8 & 95.08 & $d$ & $5.873(\mathrm{~d}, 2.1)$ \\
\hline $8 a$ & 162.49 & s & - \\
\hline 10 & 77.36 & d & $4.464(\mathrm{ddd}, 2.8,4.0,7.9)$ \\
\hline 11 & 75.13 & $d$ & $5.272(\mathrm{ddd}, 0.5,0.5,2.8)$ \\
\hline $12 a$ & 142.69 & s & - \\
\hline 13 & 116.74 & $d$ & $7.106(d, 2.0)$ \\
\hline 14 & 130.53 & s & - \\
\hline 15 & 121.36 & $d$ & 7.037 (ddd, 0.4, 2.0, 8.3) \\
\hline 16 & 116.85 & $d$ & $6.986(\mathrm{~d}, 8.3)$ \\
\hline $16 a$ & 142.47 & s & - \\
\hline 17 & 127.23 & s & - \\
\hline 18 & 111.21 & $d$ & $6.966(\mathrm{dd}, 0.5,1.8)$ \\
\hline 19 & 147.44 & s & - \\
\hline 20 & 146.49 & s & - \\
\hline 21 & 115.44 & $d$ & $6.770(\mathrm{~d}, 8.2)$ \\
\hline 22 & 119.05 & $d$ & $6.791(\mathrm{ddd}, 0.5,1.8,8.2)$ \\
\hline \multirow[t]{2}{*}{23} & 58.20 & $\mathrm{t}$ & $3.409(\mathrm{dd}, 7.9,11.6)$ \\
\hline & & & $3.338(\mathrm{dd}, 4.0,11.6)$ \\
\hline $3-\mathrm{OH}$ & - & - & $5.766(d, 5.8)$ \\
\hline $5-\mathrm{OH}$ & - & - & $11.876(\mathrm{~s},-)$ \\
\hline 7-OH & - & - & 10.490 (br.s) \\
\hline 19-OMe & 55.72 & $q$ & $3.732(\mathrm{~s},-)$ \\
\hline $20-\mathrm{OH}$ & - & - & $9.032(\mathrm{~s},-)$ \\
\hline 23-OH & - & - & 4.833 (br.s) \\
\hline
\end{tabular}

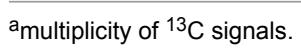

past few years. The Fukui function $f_{k}(r)$ has become one of these powerful tools, providing an atomic picture of hardness. For a given atom $k$, it is given by $f_{k}(r)=f_{k}^{+}(r)+f_{k}^{-}(r)$ where $f_{k}{ }^{+}(\mathrm{r})$ and $f_{\mathrm{k}}{ }^{-}(\mathrm{r})$ are the electrophilic and nucleophilic contributions of the Fukui function calculated as follows:

$$
f_{k}^{+}(r)=q_{k}(N+1)-q_{k}(N)
$$

and $f_{k}^{-}(r)=q_{k}(N)-q_{k}(N-1)$, where $q_{k}(N), q_{k}(N-1)$ and $q_{k}(N+1)$ are the electronic population of atom $k$ in its neutral, radical-cation and radical-anion forms, respectively. In this study, the Fukui function is used to partially rationalize $\mathrm{BF}_{3}$ complexation. In this case, the nucleophilic contribution is the 
most important parameter. It must be stressed that the higher the $f_{k}^{-}(\mathrm{r})$, the higher the atomic nucleophilic capacity. All calculations were carried out by using the Gaussian09 software [35].

\section{Supporting Information}

\section{Supporting Information File 1}

${ }^{1} \mathrm{H}$ and ${ }^{13} \mathrm{C}$ NMR spectra of new compounds, ECD spectra of new compounds, HPLC chromatograms of new compounds, table of retention times and purity of the new compounds, XYZ coordinates of optimized silybin A and B and absolute energies.

[http://www.beilstein-journals.org/bjoc/content/ supplementary/1860-5397-10-105-S1.pdf]

\section{Acknowledgements}

This work was supported by the grant P207/10/0288 (R.G.) from the Czech Science Foundation, by projects LH13097 and LD13041 from the Ministry of Education of the Czech Republic (V.K.), by the ESF COST Chemistry project CM0804 (P.T. and V.K.), and by the Institutional concept RVO61388971. P.T. and F.D.M. wish to thank "Conseil Régional du Limousin" for financial support and CALI (CAlcul en LImousin) for their computing facilities. P.T. gratefully acknowledges the support of the Operational Program Research and Development for Innovation-European Regional Development Fund (project CZ.1.05/2.1.00/03.0058 of the Ministry of Education, Youth and Sports of the Czech Republic). The authors would like to thank Dr. Petr Maloň, Institute of Physics, Charles University in Prague, for his kind assistance with ECD spectra interpretation.

\section{References}

1. Lee, D. Y.-W.; Liu, Y. J. Nat. Prod. 2003, 66, 1171-1174. doi:10.1021/np030163b

2. Kim, N.-C.; Graf, T. N.; Sparacino, C. M.; Wani, M. C.; Wall, M. E. Org. Biomol. Chem. 2003, 1, 1684-1689. doi:10.1039/b300099k

3. Graf, T. N.; Wani, M. C.; Agarwal, R.; Kroll, D. J.; Oberlies, N. H. Planta Med. 2007, 73, 1495-1501. doi:10.1055/s-2007-990239

4. Monti, D.; Gažák, R.; Marhol, P.; Biedermann, D.; Purchartová, K.; Fedrigo, M.; Riva, S.; Křen, V. J. Nat. Prod. 2010, 73, 613-619. doi:10.1021/np900758d

5. Gažák, R.; Marhol, P.; Purchartová, K.; Monti, D.; Biedermann, D.; Riva, S.; Cvak, L.; Křen, V. Process Biochem. 2010, 45, 1657-1663. doi:10.1016/j.procbio.2010.06.019

6. Schrall, R.; Becker, H. Planta Med. 1977, 32, 27-32. doi:10.1055/s-0028-1097554

7. Nyiredy, S.; Szücs, Z.; Antus, S.; Samu, Z. Chromatographia 2008, 68, S5-S11. doi:10.1365/s10337-008-0722-3

8. Křen, V.; Gažák, R.; Biedermann, D.; Marhol, P. Chromatographia 2010, 71, 167-168. doi:10.1365/s10337-009-1419-y

9. Křen, V.; Gažák, R.; Biedermann, D.; Marhol, P. Chromatographia 2010, 71, 171. doi:10.1365/s10337-009-1421-4
10. Sy-Cordero, A.; Graf, T. N.; Nakanishi, Y.; Wani, M. C.; Agarwal, R.; Kroll, D. J.; Oberlies, N. H. Planta Med. 2010, 76, 644-647. doi:10.1055/s-0029-1240624

11. Lee, D. Y. W.; Liu, Y. In Abstracts of Papers, 226th ACS National Meeting, New York, NY, United States, Sept 7-11, 2003; . AGFD-057.

12. Lee, D. Y.-W.; Liu, Y. Structure and Analysis of Flavonolignans from Silybum marianum. In Phenolic Compounds in Foods and Natural Health Products; Shahidi, F., Ed.; ACS Symposium Series; American Chemical Society: Washington, DC, 2005; pp 19-32. doi:10.1021/bk-2005-0909.ch003

13. Křen, V.; Kubisch, J.; Sedmera, P.; Halada, P.; Přikrylová, V.; Jegorov, A.; Cvak, L.; Gebhardt, R.; Ulrichová, J.; Šimánek, V. J. Chem. Soc., Perkin Trans. 1 1997, 2467-2474. doi:10.1039/a703283h

14. Křen, V.; Gažák, R.; Purchartová, K.; Marhol, P.; Biedermann, D.; Sedmera, P. J. Mol. Catal. B: Enzym. 2009, 61, 247-251. doi:10.1016/j.molcatb.2009.07.013

15. Sy-Cordero, A. A.; Day, C. S.; Oberlies, N. H. J. Nat. Prod. 2012, 75 , 1879-1881. doi:10.1021/np3005369

16. Nonaka, G.-I.; Goto, Y.; Kinjo, Y.-E.; Nohara, T.; Nishioka, I. Chem. Pharm. Bull. 1987, 35, 1105-1108. doi:10.1248/cpb.35.1105

17. Arnoldi, A.; Merlini, L. J. Chem. Soc., Perkin Trans. 11985 , 2555-2557. doi:10.1039/p19850002555

18. Fang, J.-M.; Lee, C.-K.; Cheng, Y.-S. Phytochemistry 1992, 31 , 3659-3661. doi:10.1016/0031-9422(92)83753-L

19. Da Silva, M. S.; Barbosa-Filho, J. M.; Yoshida, M.; Gottlieb, O. R. Phytochemistry 1989, 28, 3477-3482. doi:10.1016/0031-9422(89)80368-1

20. Pilkington, L. I.; Barker, D. J. Org. Chem. 2012, 77, 8156-8166. doi:10.1021/jo3015006

21. Gaffield, W. Tetrahedron 1970, 26, 4093-4108. doi:10.1016/S0040-4020(01)93050-9

22. Snatzke, G.; Snatzke, F. In Fundamental Aspects and recent Developments in Optical Rotator Dispersion and Circular Dichroism; Ciardelli, F.; Salvatori, P., Eds.; Heyden and Son Ltd., 1973; pp 109-126.

23. Anouar, E. H.; Gierschner, J.; Duroux, J.-L.; Trouillas, P. Food Chem. 2012, 131, 79-89. doi:10.1016/j.foodchem.2011.08.034

24. Slade, D.; Ferreira, D.; Marais, J. P. J. Phytochemistry 2005, 66, 2177-2215. doi:10.1016/j.phytochem.2005.02.002

25. Antus, S.; Baitz-Gács, E.; Snatzke, G.; Tóth, T. S. Liebigs Ann. Chem. 1991, 633-641. doi:10.1002/jlac.1991199101115

26. Schulte, J.; Snatzke, G. Chem. Ber. 1989, 122, 1373-1374. doi:10.1002/cber.19891220722

27. Snatzke, G.; Kajtar, M.; Snatzke, F. In Fundamental Aspects an recent Developments in Optical Rotator Dispersion and Circular Dichroism; Ciardelli, F.; Salvatori, P., Eds.; Heyden and Son Ltd., 1973; pp 148-169.

28. Snatzke, G.; Snatzke, F. In Fundamental Aspects an recent Developments in Optical Rotator Dispersion and Circular Dichroism; Ciardelli, F.; Salvatori, P., Eds.; Heyden and Son Ltd., 1973; pp 173-193.

29. Sakurai, A.; Okada, K.; Okumura, Y. Bull. Chem. Soc. Jpn. 1982, 55, 3051-3052. doi:10.1246/bcsj.55.3051

30. Tominaga, T. J. Pharm. Soc. Jpn. 1958, 78, 1077.

31. Tominaga, T. J. Pharm. Soc. Jpn. 1960, 80, 1202-1206.

32. Tominaga, T. J. Pharm. Soc. Jpn. 1960, 80, 1206-1212.

33. Tominaga, T. J. Pharm. Soc. Jpn. 1960, 80, 1212-1217. 
34. Elsinghorst, P. W.; Cavlar, T.; Müller, A.; Braune, A.; Blaut, M.; Gütschow, M. J. Nat. Prod. 2011, 74, 2243-2249.

doi:10.1021/np200639s

35. Gaussian 09, Revision A.02 ; Gaussian Inc.: Wallingford, CT, 2009

\section{License and Terms}

This is an Open Access article under the terms of the Creative Commons Attribution License

(http://creativecommons.org/licenses/by/2.0), which permits unrestricted use, distribution, and reproduction in any medium, provided the original work is properly cited.

The license is subject to the Beilstein Journal of Organic Chemistry terms and conditions:

(http://www.beilstein-journals.org/bjoc)

The definitive version of this article is the electronic one which can be found at: doi:10.3762/bjoc. 10.105 